NBER WORKING PAPER SERIES

\title{
THE IMPACT OF HEALTH AND EDUCATION ON \\ LABOR FORCE PARTICIPATION IN AGING SOCIETIES - PROJECTIONS FOR THE UNITED STATES AND GERMANY FROM A DYNAMIC MICROSIMULATION
}

\author{
René Böheim \\ Thomas Horvath \\ Thomas Leoni \\ Martin Spielauer \\ Working Paper 29534 \\ http://www.nber.org/papers/w29534
NATIONAL BUREAU OF ECONOMIC RESEARCH 1050 Massachusetts Avenue
Cambridge, MA 02138
December 2021

We thank Stefan Weingärtner for excellent research assistance throughout the project that led to this working paper. The research reported herein was performed pursuant to grant RDR18000003 from the US Social Security Administration funded as part of the Retirement and Disability Research Consortium. The opinions and conclusions expressed are solely those of the author(s) and do not represent the opinions or policy of SSA, any agency of the Federal Government, or NBER. Neither the United States Government nor any agency thereof, nor any of their employees, makes any warranty, express or implied, or assumes any legal liability or responsibility for the accuracy, completeness, or usefulness of the contents of this report. Reference herein to any specific commercial product, process or service by trade name, trademark, manufacturer, or otherwise does not necessarily constitute or imply endorsement, recommendation or favoring by the United States Government or any agency thereof. This paper builds also on previous research funded by the Bertelsmann Stiftung and published in Horvath, Kaniovski, Leoni, Spielauer and Url (2021).

NBER working papers are circulated for discussion and comment purposes. They have not been peer-reviewed or been subject to the review by the NBER Board of Directors that accompanies official NBER publications.

(C) 2021 by René Böheim, Thomas Horvath, Thomas Leoni, and Martin Spielauer. All rights reserved. Short sections of text, not to exceed two paragraphs, may be quoted without explicit permission provided that full credit, including $\odot$ notice, is given to the source. 
The Impact of Health and Education on Labor Force Participation in Aging Societies Projections for the United States and Germany from a Dynamic Microsimulation René Böheim, Thomas Horvath, Thomas Leoni, and Martin Spielauer

NBER Working Paper No. 29534

December 2021

JEL No. C5,J11,J21

\section{ABSTRACT}

Using a highly stylized dynamic microsimulation model, we project the labor force of the United States up to the year 2060 and contrast these projections with projections for Germany to assess differential effects on outcomes The projections are consistent with the U S Census Bureau's and Eurostat's demographic projections. Our modeling approach allows to show and quantify how policy changes the future size of the labor force, which we assess with a series of what-if scenarios.

Both the US and Germany are expected to undergo demographic aging, but their demographic fundamentals differ starkly. This has strong implications for their labor force developments. According to our microsimulation, the US labor force will, despite population aging, increase by 16.2 percent in the age groups 15 to 74 (corresponding to 25.2 million workers) between 2020 and 2060, while Germany will experience a decline by 10.7 percent (4.4 million workers). In these baseline projections, improvements in the education structure will add about two million persons to the US labor force and about half a million persons to the German labor force by 2060 .

In the what-if scenarios, we examine the implications of improvements in the educational structure of the population and of policies which address the health impediments for labor force participation. Of the educational scenarios that we evaluate, increasing the number of persons who achieve more than lower education has the strongest positive impact on labor force participation, relative to the number of additional years of schooling implied by the various scenarios. Shifting people from intermediate to higher education levels also increases labor force participation in higher age groups, however, this is partially offset by lock in effects at younger ages.

Our projections highlight that improvements in the labor market integration of people with health limitations provide a particularly promising avenue to increase labor force participation rates and thus help to address the challenges posed by demographic aging. If the health gap in participation rates in the United States were similar to that currently observed in Sweden, the labor force in 2060 would be larger by about 14.9 million persons.

René Böheim

Johannes Kepler University

Austria

rene.boeheim@jku.at

Thomas Horvath

WFO

Arsenal, Objekt 20

1030 Vienna

Austria

thomas.horvath@wifo.ac.at
Thomas Leoni

University of Applied Sciences Wiener Neustadt

Schlögelgasse 22-26

Wiener Neustadt 2700

Austria

Thomas.Leoni@fhwn.ac.at

Martin Spielauer

WFO

Arsenal, Objekt 20

1030 Vienna

Austria

martin.spielauer@wifo.ac.at 


\section{Introduction}

Demographic aging is a major challenge for future economic growth and the susta inability of public finances. Across the OECD, the ratio of people aged 65 and over to people of working age (15 to 64 ) is projected to rise from 25 older persons for 100 working-age persons in 2018 to 40 older persons for 100 working-a ge persons in 2050 (OECD, 2019). For a proper assessment of the economic implic ations of aging, it is howeverimportant to go beyond purely demographic considerations, as rising labor market partic ipation rates may compensate for a smaller working-age population. Projections of labor force participation a re crucial for the assessment of future revenues and costs of the social sec unity system.

We develop a dynamic mic rosimulation model to project age-specific laborforce participation in the United States while accounting for education and health. There is a long tradition of mic rosimulation modeling in the U.S., going back to models such as the DYNASIM model developed by the Urban Institute in the 1970s (Favreault et al., 2015). The mic rosimulation model that we use in this study is less complex and highly stylized, foc using on the major determinants of labor force participation, but with the advantage of a high level of transparency and international compa rability and, ultima tely, the a bility to contrast different what-if scenarios.

We use the model to compare labor force developments in the United States with developments in Gemany and contrast different policy scenarios. On the aggregate level, both the starting population and itsevolution a re modeled to be consistent with the demographic structures and projections provided by the Census Bureau for the United States and by Eurostat for Germany. We compare the U.S. with Germany because Gemany is the largest European ec onomy and has numerous features typic al of European welfare sta tes, such as (a lmost) universal public healthcare and an overall strong social safety net. The comparison is of interest also because the two countries have had different trajectories in long-term demographic and labor force participation trends in the recent past. Demographic aging is more advanced in Germany tha $n$ in the U.S. and its laborforce is expected to shrink in absolute tems in the coming decades. At the same time, Gemany introduced a number of struc tural reforms to its labor market and pension system (Seeleib-Kaiser, 2016) and - unlike the United States - has experienced a continuous rise in labor force partic ipation rates.

To assess how education and health reforms might affect laborforce participation in the coming decades, we select a series of what-if scenarios. We first examine the implications of improvements in the educational structure of the population. One of the most notable changes in the U.S. labor market in the past several decades has been the increase in educational atta inment of its labor force. For example, from 2010 to 2019, the percentage of people age 25 and older with a bachelor's degree or higher in the labor force increased from 30 percent to 36 percent (C urrent Population Survey, 2019).

Secondly, we use scenarios which highlight the potential effects of health improvements as well as of policy changes that improve the labor market integration of working-aged persons with health limitations. The OECD considers the large number of people who leave the labor market due to health limitations or disability a "social and economic tragedy" (OECD, 2010, p. 
9). Many countries have been reforming their social sec unity provisions over the last two deca des to improve the prevention and management of health-related work incapacity (Böheim and Leoni, 2018). The future labor market participation will also depend on developments in population health. While life expectancy is projected to increase in the coming decades even in the United States, where a decline was observed in the second half of the 2010s (Vespa et al., 2020; Board of Trustees, 2020) - it is less clear what impact this is going to have on the number of healthy life years and thus working life expectancy.

\section{Background}

\subsection{Projecting labor force participation}

To investigate the long-term susta ina bility of public budgets, projections from large macroeconomic models that are based on a top-down approach are often used. In the United States, Social Security Trust Fund projections a re based on macro-models that rely on various demographic, economic, and program-specific assumptions about population groupings by age and sex (TPAM 2019). Labor force projections, which are an important component of these macro-models, are typically based on cohort models. Cohort models "estimate labor force participation rates for subgroups of the population using a system of equations that holds the estimated value of the cohort effects constant ac ross certa in age groups" (Montes, 2018, p.3).

The Congressional Budget Office, for instance, uses a cohort model that estima tes la bor force participation rates by age-sex-education and race/ethnic ity subgroups. This model treats age groups within each sex-education-race subgroup as a separate system of equations and estimates cohort effects that a re constrained a cross the age group equations within each system (Montes, 2018). It builds on a string of earlier modeling work and includes a measure of the cyclic al variation in labor force participation, which is of particular importance for short- and medium-term projections. The model used by the SSA Office of the Chief Actuary (2019) projects the civilian laborforce by age, sex, marital status, and presence of children. In this model, projections of the labor force partic ipation rates "reflect changes in disability prevalence, educational attainment, the a verage level of Social Sec urity retirement benefits, the state of the economy, and the change in life expectancy" (Board of Trustees, 2020, p.108). The U.S. Bureau of Labor Statistics (BLS), too, projects the future supply of labor. It applies participation rate projections by age, gender, race and ethnic groups, which are developed using data from the Current Population Survey (CPS), to population projections produced by the Census Bureau (BLS, 2021).

In Europe, the discussion of economic and social policy issues is informed by the macroeconomic scenarios included in the EU Commission's Ageing Report (European Commission, 2017, 2018, 2020, 2021). In the Ageing Report projections, employment rates are extrapolated into the future using a dynamic cohort model. This cohort model is based on age-dependent proba bilities of labor market entry and exit over the last ten years. The entry and exit rates a re then used to project future employment rates as older generations are gradually replaced by younger ones, taking into account pension reforms from the recent past. Except for interven- 
tions due to changes in pension legislation, both average entry and exit rates are kept constant. Although the aging process does have an impact on the aggregate employment rates, changes in behavior and differences between groups of people beyond cohort membership are not included in the projection model.

These approaches place high demands on the consistency between assumptions of different modeling levels. In its report to the Social Sec unity Advisory Board, the Technic al Panel on Assumptionsand Methods recommends using mic rosimulation techniques that a re more bottomup than current macroeconomic models, thus ensuring more consistency of the underlying assumptions (TPAM, 2019). The Technical Panel also stresses the need to model dynamic impacts and what-if scenarios to gain insights on the potential effects of policy changes on macro-economic indic ators. Mic rosimulation allowsa more explic it incorporation of theory and polic y levers in projections, for example, modeling inter-generational educational dynamics and the analysis of downstream effects of education policy interventions on la bor ma rket outcomes (Spielauer and Dupriez, 2019). Microsimulation has proven to be a partic ularly useful tool to a nswer 'What if..?' questions (Za idi and Rake, 2001). Van Hook et al. (2020), for instance, a pply a dynamic mic rosimulation model to evalua te the long-run implic ations of va rious immigration policy proposals for the skill levels of the future labor force in the United States. Their demographic model (LSD-USA), which focuses on demographic outcomes, was originally developed for Canada, othermodels of this family were adapted fordifferent European countries (Marois et al., 2019; Marois and Aktas, 2021).

The mic rosimulation model that we use in this study (www.mic roWELT.eu) is highly stylized, allowing us to foc us on the major determinants of labor force participation, with the advantage of a high level of transparency and intemational comparability. On a technical level, our model allows for interacting populations and is designed as a modeling platform for welfare transfers. The benefits of the dynamic mic rosimulation approach we develop here are a consistent set of assumptions, the ability to quantify the effect of single parameter changes on aggregate outcomes, and, ultimately, the ability to contrast different what-if scenarios. There is a bundant evidence that both participation behavior and employability, i.e. the chances of success on the labor market, a re influenced by a host of factors. These include individual characteristics (such as skill-level, household composition, and health status), contextual factors

(such as gender roles and work noms), and polic ies (such as retirement regulations and labor market institutions). In the following analyses, we place particular attention on education and health as determinants of labor force participation.

\subsection{Education and health as deteminants of participation}

\subsubsection{Education}

Human capital theory postulates a positive effect of human capital on labor force partic ipation (Mincer, 1974; Becker, 1976). Empinically, there is a strong positive relationship between education and wages (Gold in and Katz 2009; O reopoulos and Petronijevic, 2013). Higher education is a Iso associated with other factors that positively affect la bor force participation, such as better employment perspectives, more enjoyable job tasks, and lower workplace health risks (Laplagne et al., 2007). Across the OECD, on average, the labor force participation rate 
of individua ls who completed tertia ry educ ation is a bout 24 percentage points higher than the rate for individuals who have not completed high school, i.e. an upper secondary education (Figure 1). This difference is in the United States (23.3 percentage points) and in Germany (23.9 percentage points) close to the OECD's average.

Figure 1: Labor force participation, by educational level

Labor force participation rate, age 25 to 64,2018

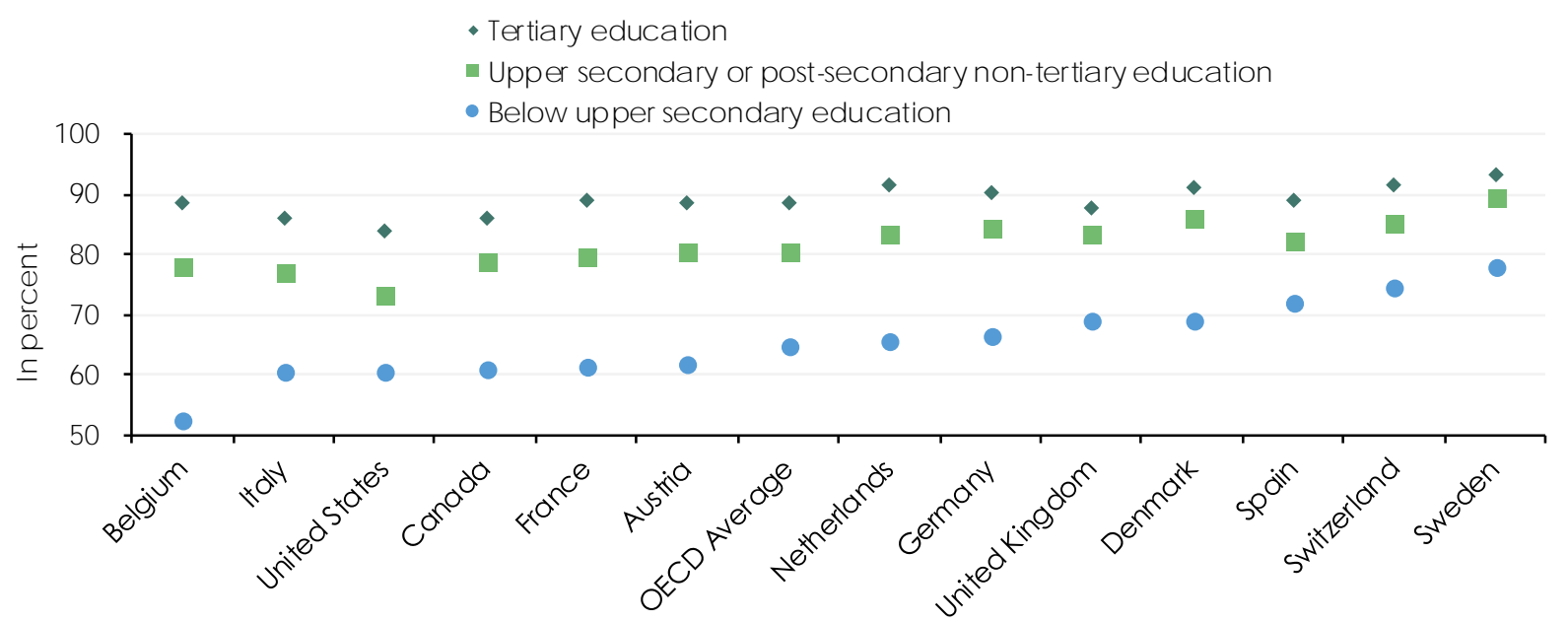

S: OECD.Stat (2020) [Educational attainment and labor-force status]. - Educational level according to ISCED 2011 A.

The labor supply of women, in partic ular, is influenced by a host of other factors, associated with gender roles and aspirations as well as with specific institutions, such as the ava ilability of care senvices (Folbre, 1994; Del Boca 2002; J a umotte, 2003; Femández et al., 2005). Several of these factors interact with education and educational choic es, resulting in a stronger positive correlation between educational atta inment and labor force participation forwomen than for men. In virtually all advanced economies, the participation gap between those with high or lower formal education is much more pronounced for women than it is for men (OECD.Stat, 2020). The gap a mounts to 33.2 percentage points for women and 15.8 percentage points for men in the United States, in Gemany the difference is 29.4 percentage points for women and 16.4 percentage points formen. Formal education and future educational trends can thus be expected to impact more strongly the projection of laborforce participation rates for women than formen.

\subsubsection{Health}

Poor health can affect a person's productivity or it might be interpreted by an employer as an indic ator of low productivity. Poorer health likely leads to fewer job offers as well as - through the link between productivity and eamings - to less labor supply. Thus, similar to education, health correlates positively with employment and labor force participation, and health and education a re positively correlated with each other (Lund borg, 2013; Grossman, 2015). Figure 2 shows that the correlation is stable over the life-cycle and it can be observed for both the 
employed and the total population. Measuring the causal links between education and health, however, is challenging, not least because of third factors that may cause health and education to vary in the same direction (Cutler and Leras-Muney, 2010; Eide and Showalter 2011; Grossman 2015). In our microsimulation, we will model health depending on demographic characteristic sas well as education.

The future labor market participation will depend, at least in part, on developments in the health status of the population. Life expectancy is projected to increase in the coming decades, even in the United States where a decline could be observed in the second half of the 2010s (Vespa et al., 2020; Board of Trustees, 2020)..$^{1}$ It is less clear, however, to what extent the number of healthy life years and thus working life expectancy will change. The question of whether we will witness an "expansion of morbidity", a "dyna mic equilibrium" or a "compression of morbidity" (Crimmins and Beltrán-Sánchez, 2011) is la rgely an empirical one and might be answered differently depending on the country and time period studied.

Figure 2: Share of people reporting poor health by employment status and education

OECD countries, age 20 to 64

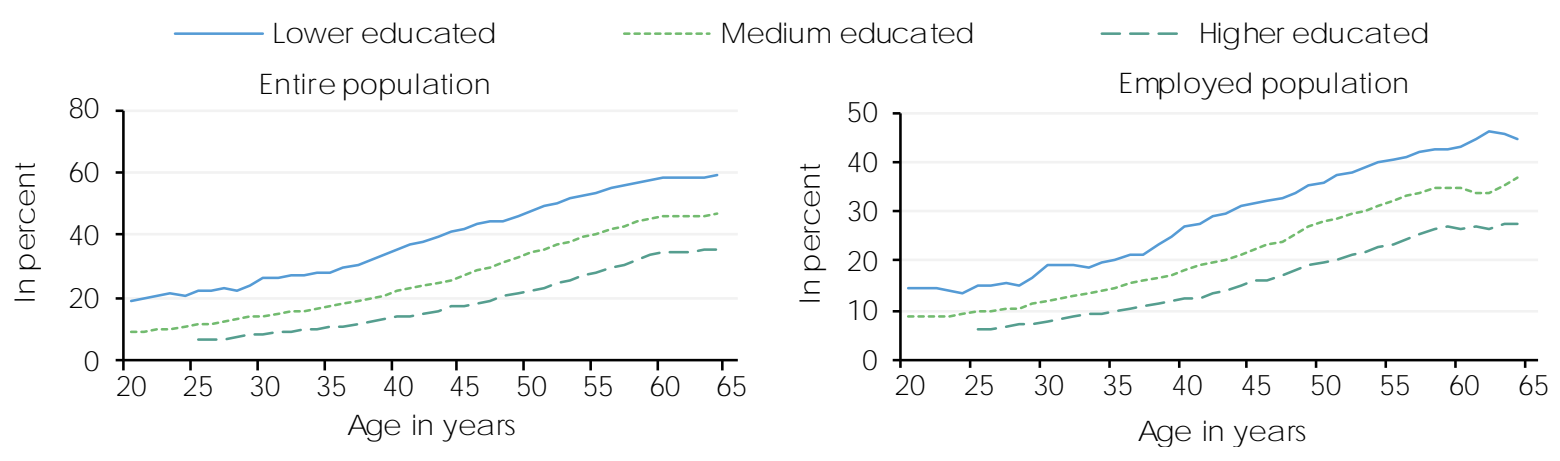

S: OECD (2017). - Based on pooled waves of different survey mic rodata. Health status is self-reported. Poor health refers to the answercategories lower than "good", i. e. "very bad", "bad" and "fair" (as opposed to "good" and "very good") or "poor" and "fair" (as opposed to "good", "very good" and "excellent"), depending on the survey.

Poor health and disability are generally associated with reduced chances of obtaining and rema ining in employment (Sc huring et al., 2007; Geiger et al., 2019). The extent to which health impacts la bor market activity does, however, vary greatly in intemational comparison, and the effect a lso depends on labor market institutions and policies. Disability pensions are an a rea where this intemational heterogeneity is partic ula rly evident. Börsch-Supan et al. (2009), for instance, find that the large differences in old-age laborforce participation and disability-benefit recipiency rates a cross European countries a re a lmost entirely due to institutional differences such as the generosity of benefit and the minimum requirements for disability benefits, while differences in health status play only a minor role. The labor market inclusion of workers with health problems does however not depend only on the design of disability benefits, but on a broader range of policies to promote employment and support reintegration (OECD, 2010).

\footnotetext{
1 These projections, however, do not yet take into account the effects of the COVID-19 pandemic.
} 


\subsubsection{Polic ies for the inc lusion of workers with health problems}

Figure 3 shows public spending on health-related inc apacity for selected OECD countries. ACcording to the OECD's definition, health-rela ted incapacity includes benefits for sic kness, disability, and occupational injury, as well as for senvic es for disabled persons. In these countries, public spending on incapacity was about 2 percent of GDP in 2015. Even without including costs to the health care system, these costs often exceed public spending on unemployment benefits and labormarket programs (OECD, 2020). This is the case in the United States, as well as in Germany.

Figure 3: Public spending on incapacity and on labor market programs

Share of GDP, 2015

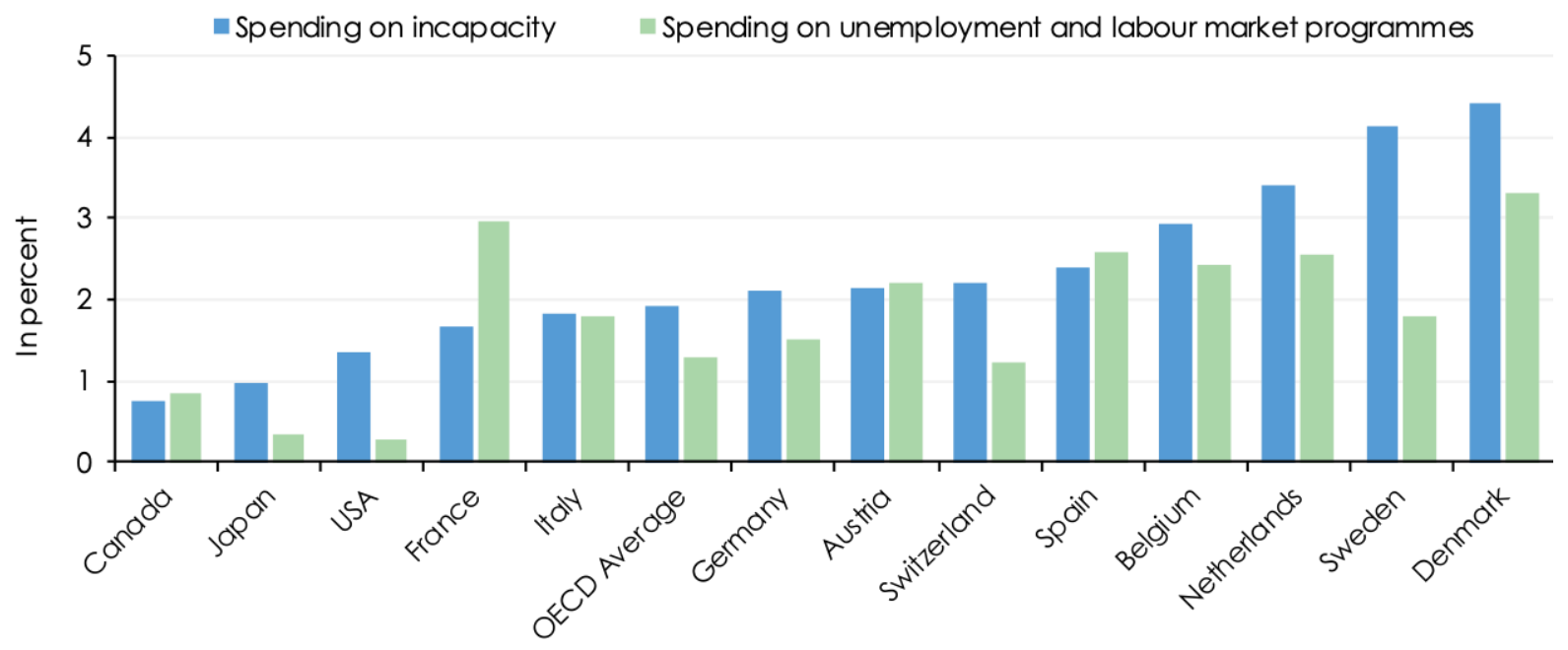

S: OECD (2020). - Public spending on incapacity refers to spending on benefits for sic kness, disa bility, and occupational injury, as well as on services for disabled people. Public spending on labor market programs includes public employment servic es (PES), tra ining, hining subsidies and direct job creations in the public sector, as well as unemployment benefits.

Many countries have been reforming their social security provisions to improve the prevention and management of health-related work incapacity. Figure 4 shows that overall there was a broad shift towards "integration" polic ies, whic h reflec ts the effort of many countries to ac tiva te people with health problems. ${ }^{2}$ Typical measures are, among others, the introduction of early intervention programs, the promotion of vocational rehabilitation measures, a stronger focus on workers' residual work a bility, as well as the involvement of employers in preventing a permanent exit from the labor market in case of illness (Böheim and Leoni, 2018). In contrast, we

\footnotetext{
2 The OECD classified sickness and disability policies in its member states to track reforms (OECD, 2003, 2010). The classification consists of two main policy indicators, each in tum consisting of ten sub-dimensions. The "Compensation" indic ator provides an overall assessment of polic y features related to the benefit system (such as benefit generosity and coverage, eligibility criteria, etc.). The "Integration" indic a tor captures the intensity of mea sures for activation and employment integration (such as employer obligations, sheltered or supported employment programs, work incentives, etc.). These indic ators were updated by Böheim and Leoni (2018).
} 
observe moderate reductions in the indic ator for "compensating" policies. Changes mainly a imed at reducing the inflow to the benefits, e.g., through shorter benefit permanence and greater stric tness in benefit assessment criteria (and much less through a reduction in benefit replacement rates).

Despite a common trend towa rd sincreasing activation, sic kness a nd disa bility polic ies still vary substantially between countries. There is a lack of comprehensive evidence on the effects of different policy strategiesand reform paths on the laborma rket outc omesand welfare of working-age people with poor health. Generally speaking, countries that have dealt more intensively with integration policies have higher activity rates or have at least experienced a more favorable development over time than those which have lacked these reform processes. Switzerland, Sweden, and the Netherlands, for example, achieved a marked decline in disability benefit claims and an increase in employment rates of older workers with poor health (OECD, 2014; Koning and Lindeboom, 2015; Böheim and Leoni, 2018; Hemmings a nd Prinz, 2020).

Figure 4: Trends in sickness and disability programs, OECD policy indicators

Selec ted OECD countries, 1990 and 2014

1990

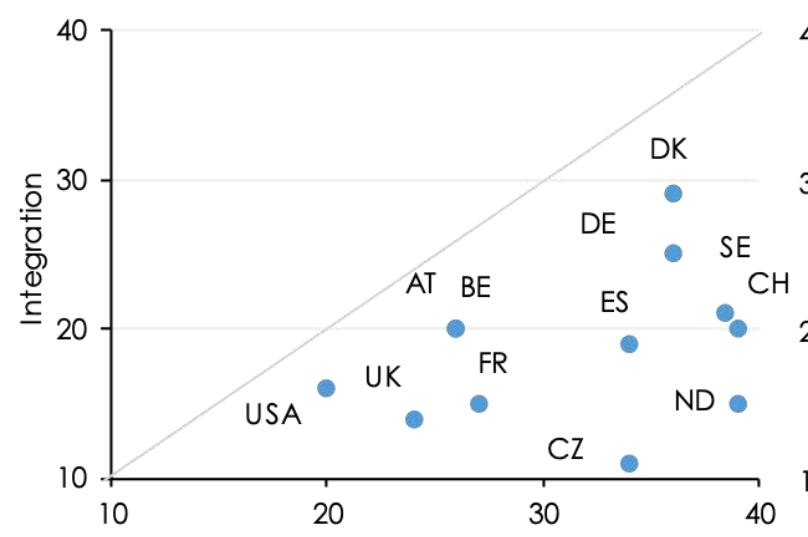

2014

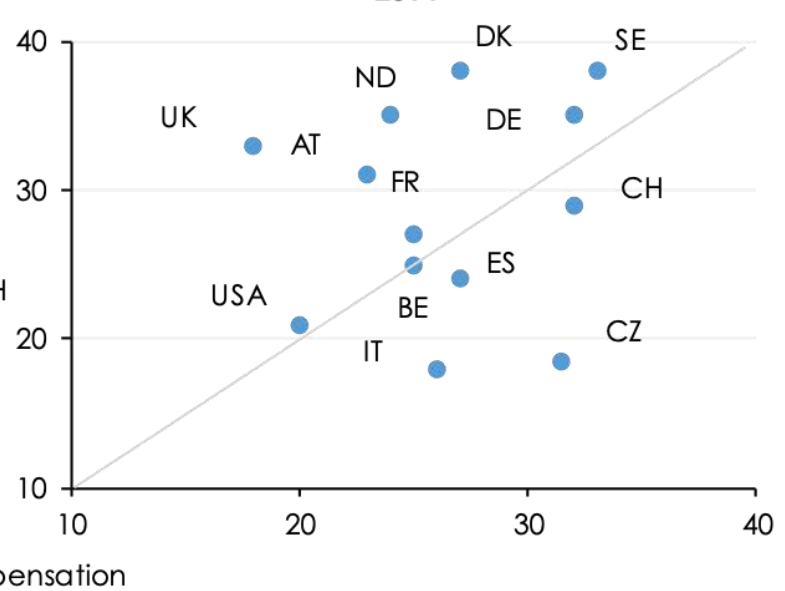

S: OECD (2010), Scharle, Váradi and Samu (2015), Böheim and Leoni (2018).

To sum up, while the health of the working-age population, and in particular that of older workers, is an important determinant of future participation rates, the extent to which the labor market inclusion of workers with health problems can be affected by appropriate polic ies and institutions should not be underestimated.

\subsection{Demographics and labor force partic ipation in the United States and Gemany}

The United States and Gemany display some marked differences with respect to their demographic and laborforce participation dynamics.

According to the most recent census projections (Medina et al., 2020), total life expectancy in the U.S. is projected to increase from 79.7 in 2017 to 85.6 yea rs by 2060 . Over the same period, 
the population is projected to grow by nearly 79 million people, from about 326 million to 404 million (Vespa et al., 2020). The size of the older population is projected to grow even faster and by 2060 at least 25 percent of the U.S. population is projected to be at least 65 years old. An increase in the labor force participation rate (LFPR) could help to cushion the negative impact of aging. In the recent past, however, labor force partic ipation has not evolved favorably in the United States. After peaking a round the year 2000 at about 67.3 percent, the U.S. LFPR dec lined until about 2015, and has rema ined stable at about 63 percent since then (Perez-Arce and Prados, 2021). During the same period, the LFPR of most other economic ally advanced countries increased (OECD, 2021). Aa ronson et al. (2014) and Krueger (2017) suggest that about half of the decline in the U.S. is due to long-running demographic changes. In their summary of the litera ture, Perez-Arce and Prados (2021) argue that this could even a mount to two-thirds.

However, otherfactors, such as increased schooling, the opioid epidemic, and social sec unity programs such as the Social Security Disability Insurance (SSDI) may have also contributed to the dec line in the LFPR. A detailed a nalysis by demographic sub-groups reveals a reduction in participation for prime working-aged persons and the youth of both genders (Abraham and Keamey, 2020). Between 2000 and 2017, the participation rate of young men dropped from 68.1 percent to 56.3 percent, and for young women from 63.2 percent to 54.1 percent. The participation rate of prime age working men declined slightly in this period, from 91.5 percent to 89.1 percent. At the same time, the LFPR of prime working-age women, which had risen to 77 percent in the late 1990s and remained stable there until around 2000 , fell to 75.2 percent in 2017.

Although there is a consensus that life expectancy is likely to inc rease in the next decades, it is less clear how an aging population will affect the LFPR. While older people are more likely to suffer from poor hea lth that limit or prohibit their work, current generations of older adults are more ac tive than previous generations (Czaja , 2020). For exa mple, the LFPR of persons who a re 65 to 74 yearsold wasabout 25.6 percent in 2009 , it was 27.8 percent in 2019 , and it is projected to increase to 33.2 percent by 2029 (BLS, 2021). Overall, however, the BLS expects the LFPR for the total population to decline, from 63.1 percent in 2019 to 61.2 percent by 2029 (Dubina et al., 2020). In its 2021 long-tem budget outlook, the CBO assumes that the LFPR for the total population (aged 16 or older) will decline to 60.2 percent in 2060 (CBO, 2021A).

Unlike the U.S., where the population is set to keep growing, the demographic projections by the European Commission (2021) indicate a declining population size for Gemany between 2019 and 2060, from a bout 83.1 million to about 81.8 million people. The sha re of the population who are older than 65 years of age is projected to grow from 21.7 percent in 2019 to 28.3 percent by 2060. At the same time, the share of the population aged 20 to 64 years is projected to dec line from about 60 percent in 2019 to a bout 52 percent in 2060.

The LFPR of the German working-age population (15 to 64 years) has increased from 65.4 percent in 2000 to 76.7 percent in 2019. ${ }^{3}$ Accord ing to the Ageing Report, laborforce participation

\footnotetext{
3 Destatis, https://www.destatis.de/DE/Themen/Arbeit/Arbeitsmarkt/Erwerbstaetigkeit/Tabellen/erwerbstaetigenquoten-gebietsstand-geschlecht-a ltergruppe-mikrozensus.html.
} 
rates are projected to rema in constant between 2019 and 2060 for younger persons (aged 20 to 24) and to increase slightly for workersaged 25 to 54 years and forthose aged 55 to 64 years. The LFPR of old persons (65-74) is projected to increa se from 13.9 percent in 2019 to 18.3 percent in 2060, reflecting legislated pension reforms. In the aggregate, the LFPR of the population aged 20 to 64 years is estimated to inc rease from 83.2 percent in 2019 to 84.1 percent in 2060 . while the corresponding rate for those aged 20 to 74 years is set to dec line slightly, from 73.1 to 71.9 percent. The financial pressure on the German Pension Insurance will increase, due to the increased old-age dependency ratio, and the increase of the retirement age to 67 is not likely to counter the demographic trend.

\section{Figure 5: Participation rates for individuals in good and poor health, by age}

Age 20 to 64, United States and Germany

US - Male

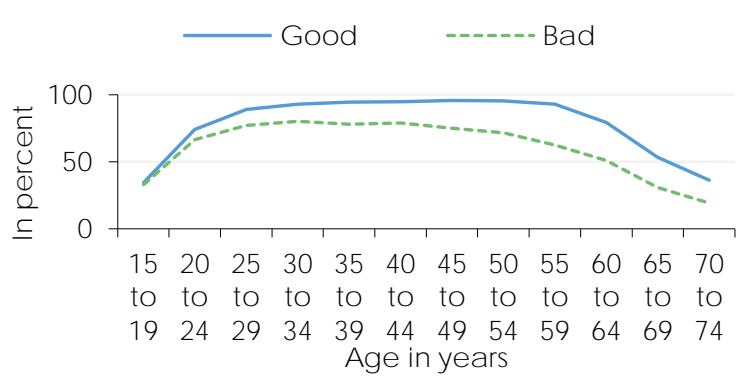

DE - Male

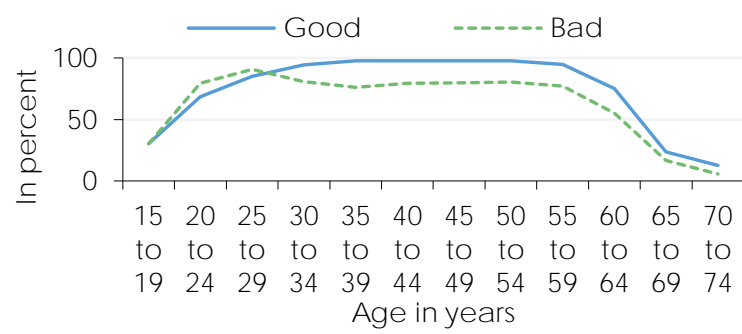

US - Female

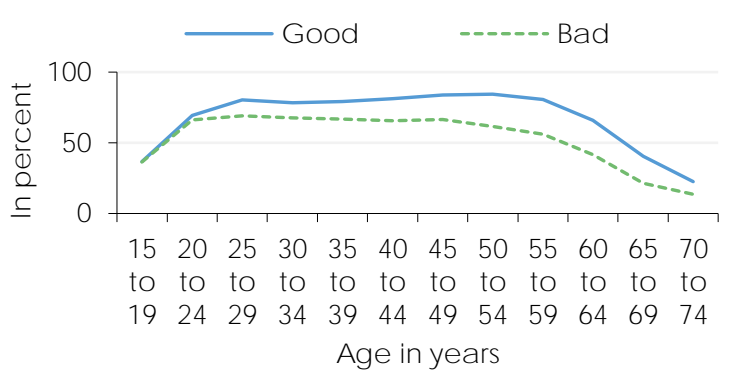

DE - Female

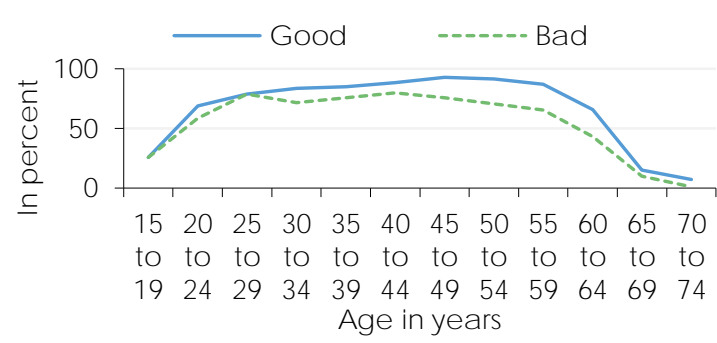

S: Own calculations based on ASEC (2017) and EU-SILC (2014) data. People in bad health are defined as those in the bottom tertile of the health distribution, as mea sured with a latent health indicator based on several health indicators included in the surveys.

Both in the United States and in Germany, the employment rates of persons who report poor health are consistently below those of persons in good health, for men and women of all age groups. Employment rates of older persons a re lower than those of younger persons, irrespective of health status. In relative tems, however, the gap in employment rates between those in poor and those in good health increases with age. Figure 5 shows that the likelihood of participating in the labor market is about 10 to 15 percent greater for healthy individuals in the age groups 30 to 44 than it is for those in poor health, but the gap is almost twice as high for persons aged over 60 . As the absolute participation rates of older groups a re projected to increase in the future, the absolute health gap in these age groups might increase. The actual development will however depend on the number of healthy life years and if working life expectancy 
will expand, as well as on increased support for the employment of workers with health impa irments.

In the United States, there were few reforms of sickness and disability during the last two deca des. Momis (2016) points out that this lack of reform activity can at least partly be expla ined with the structural a rangements of the Social Sec urity Disability Insurance (SSDI). G eiger et al. (2019) stress that the U.S. is exceptional as it is the only country of the 12 they compared where the employment of older workers with ill-health deterio rated between 2004 and 2015: "Not only did the gap between the employment rates of those with poor health and good health increase in the USA (by $8.1 \%$; $95 \% \mathrm{CI} 4.8-11.4 \%$ ), but the employment rates of those with poor health perse fell (by $4.5 \%, 95 \% \mathrm{Cl} 1.8-7.3 \%) . "$ (p.30).

In contrast, Gemany took several steps to strengthen the integration dimension of its sickness and disability polic ies, notably with the institutionalization of disability management (Betriebliches Eingliedenungsmanagement) (Geiger et al., 2019). Other polic ies were the introduction of the right to rehabilitation (in 2001) and of sickness absence monitoring (2004). The reform of 2004 also requires fims to offer employees who are sick for more than 6 weeks support for their retum to work. More recently, Gemany undertook steps to increase the use of graded sick leave schemes, a imed at facilitating retum-to-work after longer health-related absences from work (Leoni, forthcoming).

\section{Method}

Dyna mic mic rosimula tion modelsa re suita ble forforecasting the long-term soc io-demographic development of a population and a nalyzing the susta ina bility and a dequacy of tax and social security systems. Dynamic microsimulation was already proposed as a method for economic research when the first computers were a vailable (Orcutt, 1957). In Europe and the U.S., dynamic microsimulation is predominantly used in pension simulation models (Gál et al., 2009). Such models a re usually very deta iled country-specific applic ations for country-specific data. In contrast, we use a highly stylized model, mic roWELT-US, for public ly ava ilable standardized data which allows better to compare the impact of polic ies in different countries.

While multi-country compara tive a pplic a tions a re a recent development in dyna mic microsimulation, the benefits are well demonstrated in tax-benefit microsimulations, as with the European Union tax-benefit microsimulation model Euromod (Sutherland and Figari, 2013; Browne and Immervoll, 2017). We develop the dynamic mic rosimulation model mic roWELT-US building on the mic roWELT (www.mic roWELT.eu) modeling platform, and on recent work extending this platform for labor force projections in Europe (Horvath et al., 2021). mic roWELT was designed as an adaptable, extendable, and portable tool for comparative studies of welfare transfers. mic roWELT-US is designed for compa rative la bor force projections that account for educ ation, health, and family characteristic s. The core of mic roWELT-US consists of demographic models, supplemented with socio-economic processes (education and employment) as well as the modeling of health statuses. 
In labor force projections, mic rosimulation allows the explic it consideration of influencing factors such as education, health or the age of children as key determina nts of labor force participation. By simulating ind ividua Is in their fa mily context, intergenera tional proc esses such as the intergenerational transmission of educ a tion a re accounted for. mic roWELT-US explic itly models morta lity, fertility, the formation and dissolution of partnerships, partner matching, education, migration, leaving parental home, health, and labor force participation. Education is a key factor in most of mic roWELT-US's modules and influences labor force directly and ind irectly via differences in family characteristics (e.g., lower fertility of higher educated women), the education-specific prevalence of health limitations, and differential mortality. One of the critical fea ture s of mic roWELT-US is its inbuilt ability to reproduce existing population projections in aggregate outcomes such as age-specific fertility, mortality by age and sex, and net migration by age and sex.

mic roWELT-US is a continuous-time, competing risk, and interacting population model. We select a starting population from cross-sectional data that are representative of the underlying population of their country of residence in 2014 for Gemany and 2017 for the United States. All individuals a re simulated from birth, making it possible to impute some processes, such as education histories, retrospectively. The simulation size (the number of simulated persons) is independent of the size of the starting population and, while it can be freely chosen, is set to the countries' population sizes in 2014 for Germany and 2017 for the United States. The model also a llows several replic a tes to be simulated in parallel to provide distributional information on random fluctuations in the results (Monte Carlo Variation).

The model is implemented in continuous time, i.e., different events (such as births or deaths) can occur at a ny time, so an update of individual characteristic s is not restric ted to fixed intervals (such as years). While this approach is technic ally more complex than the "classical" approach of periodic updates, it is a natural a pproach from a life-cycle perspective. In thisframework, changes in one process can immediately impact other processes just as they happen. As an interacting population model, all individua ls are simula ted simulta neously and may influence each other at any time. This approach allows for continuously updated links between family members and to model family formation by the matching of spouses. Moreover, the approach allows for the automatic a lignment of simulation results to extemal population projections, if desired.

The model is implemented in Modgen, a generic mic rosimulation programming language developed and ma inta ined by Statistic s Canada. mic roWELT-US is highly modula rand suita ble for further refinement or extension. For a detailed documentation of the model, its a rc hitec ture, its modules, as well as its parameterization (base scenario) see the technical report (Amann et al., forthc oming).

\section{Data}

For the U.S., we use data from the ASEC public use file data (2017). For Germany, data from the 2014 European Union Statistics on Income and Living Conditions (EU-SILC) and from the 2017 EU-SILC ad-hoc module "Health and children'shealth", conta ining health-related variables 
not included in the standard EU-SILC data (information on self-rated health, health limitations, and healthcare service use), are used. Data on population projections and their underlying assumptions conceming fertility, mortality, and net-migration a re taken from the U.S. Census Burea $u$ and Eurostat.

Health status is modeled with a latent health indic ator, enabling to order individuals within each c ountry a long with the hea lth distribution. We follow an a pproach developed by Poterba et al. (2013) where different varia blesa re combined into a single measure of la tent health using a principal component a na lysis (PCA). This a pproach a ims to id entify, for ea ch country separately, equally sized groups of people with relatively poor health, and to compare their labor market outcomes with those of persons with better health. Persons whose health ind icator is in the lower third of the distribution are considered to have health restrictions. The indic ator increases with a ge and is negatively correlated with the level of education.

Formal educational atta inment is classified differently for the United States and Gemany. For Germany, we distinguish four levels of education, corresponding to ISCED 0-2, ISCED 3, ISCED 4, and ISCED 5+. In Germany, ISCED 4 is of higher importance than in other OECD countries, because it includes the comparably large share of persons who start an apprenticeship after graduating from ISCED 3 level school-types (Abitur). With respect to the United States, education is grouped into four level: the ISCED 0-2 level corresponds to education up to the $9^{\text {th }}$ grade and ISCED 3 to $10-12^{\text {th }}$. ISCED 4 does not have a propercorrespondence in the U.S. educational system. ISCED level 5 corresponds to some college (without obtaining degree), community or junior colleges, or voc a tional technic al institutes (non-university) leading to an assoc iate's degree. ${ }^{4}$ ISC ED levels $6+$ refer to universities or other 4-year education institutions lea ding to a bachelor, master, or doctoral degree. To acknowledge the difference between the German and the U.S. educational system, we use a slightly modified classific ation where we distinguish between four levels: level 1 "below high-school" (ISC ED 0-2), level 2 "high-school" (ISC ED 3), level 3 "(some) college" (ISCED 5), and level 4 "university" (ISCED 6+) educational c ategories.

We model three educational processes: (1) school enrolment, (2) education atta inment, and (3) the intergenerational transmission of education (i.e. the influence of the parents' education on the education of their children). To model this third process, we use information on respondents' and their parents' educational atta inment included in the OECD PIAAC data for the U.S. and in the 2009 ad-hoc module "Entry of young people into the labor market" of the EU-LFS data for Gemany. Figure 6 depic ts the projected education attainments of persons aged 25 to 59 between 2020 and 2060 according to our baseline projections. As we can see, the two highest education groups increase in size in both countries. However, the United States currently have a signific antly higher sha re of the population with at least some college education. Germany, which has a larger share of the population attaining the first or second educational levels, undergoes a catching-up process and therefore a stronger educational expansion.

\footnotetext{
4 See information provided by the National Center for Education Statistics (NCES), https://nces.ed.gov/pubs/eiip/eiip1s01.asp [retrieved 2021-09-10].
} 
Figure 6: Education composition of the population 25-59 by calendar year

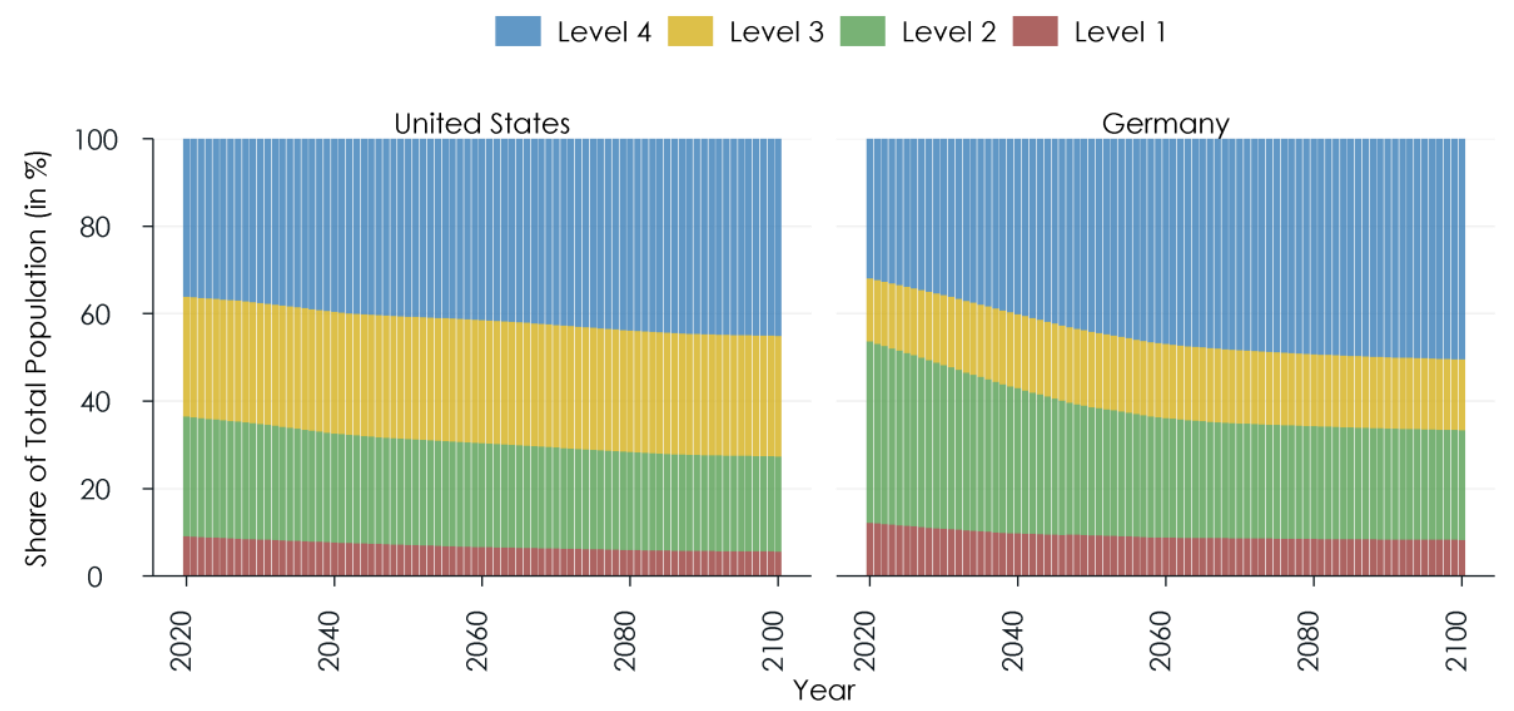

S: mic roWELT simulation results - base scenario. Own calculations based on CPS Annual Social and Economic Supplements 2017, OECD PIAAC data and EU-SILC 2014. Level 1: below high school (ISCED 2 for European countries); level 2: high school (ISCED 3); level 3: (some) college (ISCED 4); level 4: university (ISCED5+).

\section{Results}

\subsection{Baseline}

In our baseline simulations, changes in education level affect labor force participation in different ways. Higher education leads to more labor force participation, particularly in higher a ge, but due to a lock-in effect, la borforce partic ipation decrea sesforyoungerpersons. Figure 7 shows how labor force participation varies over age and education levels for men and women in the U.S. and Germany (baseline simulation for 2020).

In both countries, we observe a positive education gradient in participation. In accordance with the literature, the variation in simulated participation by educ ation is stronger for women than formen. This is partic ula rly evident when we compare the group with least formal education (ISCED 0-2 and "below high-school") with the remaining groups. Differencesin participation rates between the group with intermediate and the group with most formal education are much less pronounced. We find the most notable difference between the U.S. and Gemany for those who have most formal education: In the U.S., partic ipation rates of persons with college and university education differ greatly, whereas in Gemany both men and women with ISCED 4 level have a participation behavior that is similar to that of the group with university education. In Germany, the ISCED 4 level includes mainly persons who, after completing a high-school also complete an apprenticeship tra ining. About 20 percent of a cohort has both a high-school leaving certific ate and completed an apprenticeship (Bellmann and Prümer, 2021). This is indicative of the strong labor-market orientation of the dual education track that characterizes the German educational system. 
Figure 7: Labor force participation by age and highest level of education

United States and Gemany (2020)
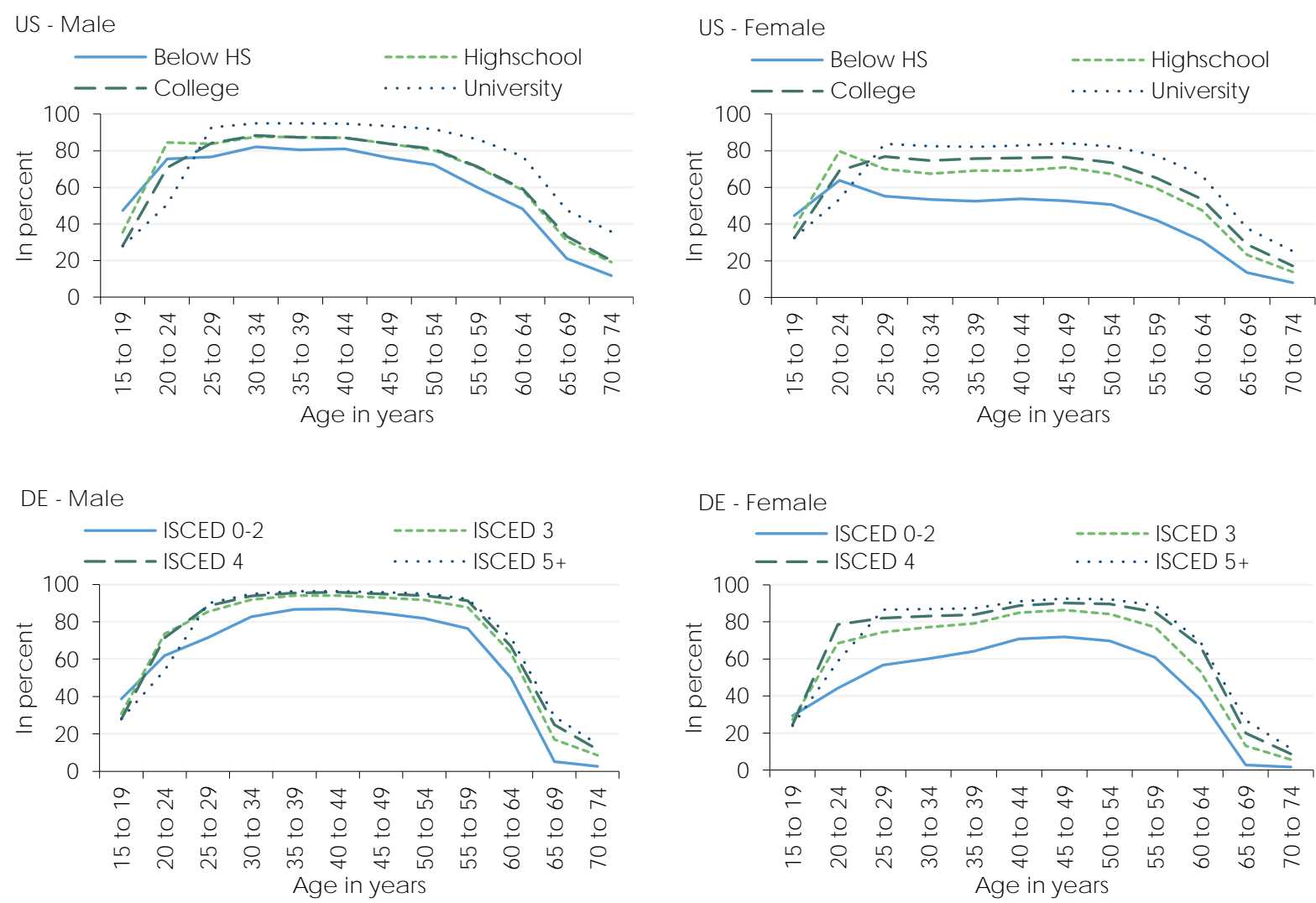

S: WIFO.

Figure 8 shows how labor force participation rates by age group in Gemany and the U.S. change overtime under the assumptions of our baseline scenario. Our baseline projections for Germany show labor force participation rates that are, in the aggregate and up to the year 2030, similar to those in the EU Commission's Ageing Report and are, after 2030, marginally higher (European Commission, 2018). The Ageing Report projec ts consta nt or slightly inc rea sing participation rates of the younger age group ( 15 to 24 years). Our baseline results, in contrast, project a decline in labor force participation in the younger age group. This is consistent with the educational shift that is part of our modeling approach as longer educational trajectories lead to a lock-in effect that delays labor market entry.

For the United States and the age group 15 to 74, our projections show a total LFPR in 2060 (66.2 percent) that is a lmost at the sa me level a s in 2020 (66.0 percent). This is slightly more optimistic than the most recent BLS and CBO projections, where total LFPR is projected to decrease slightly. Unlike the BLS and CBO projections, we do not differentiate by race/ethnicity and therefore might project a more positive impact of demographic change on labor force participation. A more accurate comparison between the different projections is however diffic ult, 
partly because of differences in the age definitions, the levels of disaggregation, and the granularity of published results. The projec tions provided by the CBO as supplement to its 2021 Longterm Budget Outlook, for instance, define working age people as those aged between 16 and 89 years (CBO, 2021B).

Figure 8: Labor force participation rates 2020 and 2060

United States and Gemany, baseline
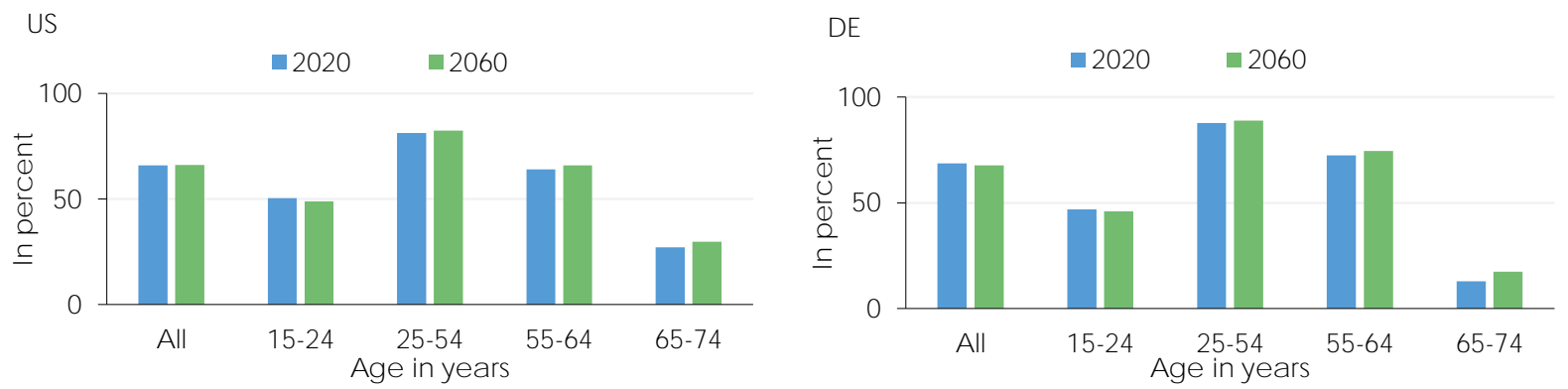

S: WIFO

Figure 8 shows how the projected size of the labor force evolves over time in the U.S. and Germany. The graph highlights the stark contrast in labor force dynamics between the two countries, which is mainly driven by diverging demographic fundamentals. According to our simulations, the U.S. labor force will increase by 16.2 percent between 2020 and 2060, while Germany will experience a dec line by 10.7 percent. 5 The total changes in the baseline's projection of the labor force over the period 2020 to 2060 can be decomposed into different components, which indicate how changes in the size and age structure of the population, changes in educ ational attainment, and pension reforms (e.g., increa ses in regular retirement age) impact on future labor force size (Figure 10).

The population effect shows the change in laborforce that comesfrom demographic change, under the assumption that the age-specific labor force participation rates rema in the same overtime. In Germany, the demographic change negatively impactsthe size of the laborforce in virtua lly all age groups. The nega tive effect is particularly large for the a ge group 50 to 59. In the United States, in contrast, population growth increases the labor force in all age groups, a lbeit much less in the age groups below 30 than in the other groups.

\footnotetext{
5 In absolute terms, this corresponds to an increase by about 25.2 million workers in the United States and a decrease by close to 4.4 million workers in Germany (in the age groups 15 to 74). Our projection for the U.S. is, a ga in, marginally more optimistic than that provided by the CBO long-tem outlook. According to the latter, between 2020 and 2051 the U.S. civilian labor force will increase by 12.1 percent, according to our microsimulation over the same period the increase will be by 13.4 percent.
} 
Figure 9: Change in the size of the labor force (relative to 2020)

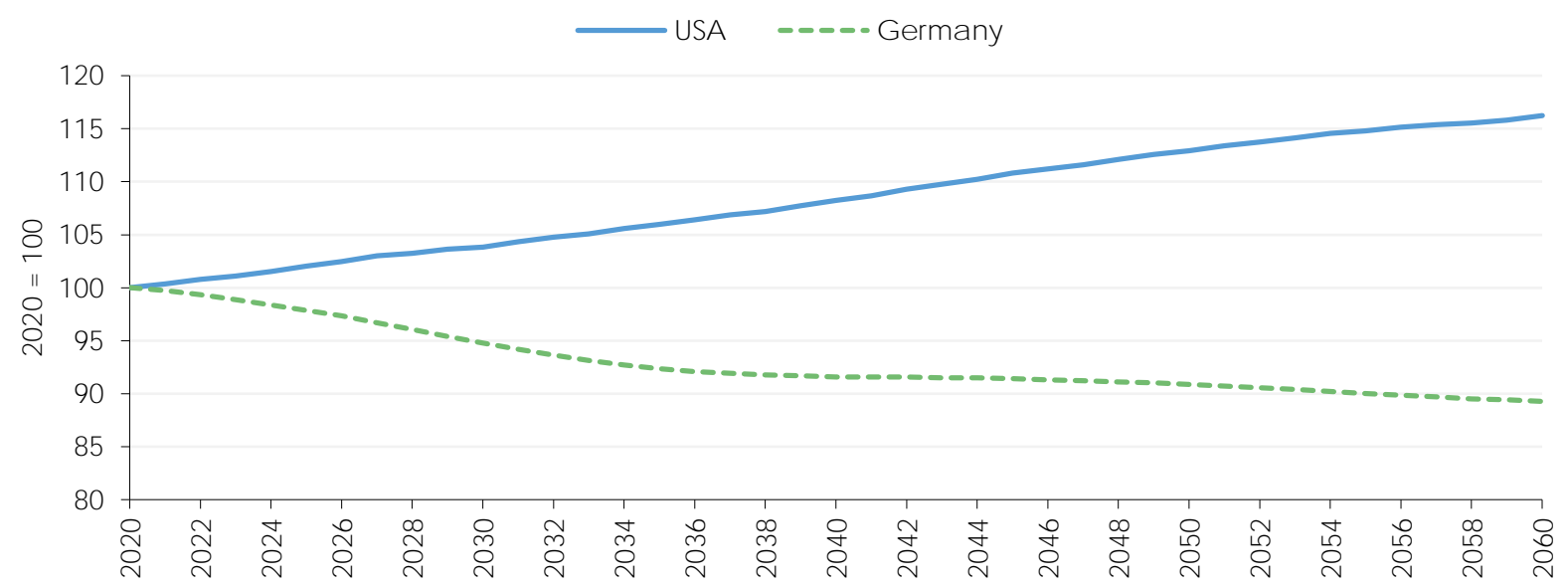

S: WIFO.

The education effect shows how the change in the education structure of the population will affect the projected laborforce. In the young age groups, educational expansion reduces the projected size of the laborforce. This is due to a lock-in effect of highereduc ational trajectories. The educational effect is, however, positive for the prime working-age groups and is greater for older than for younger age groups. The largest effects in both countries are projected for the age group 55 to 64 . In total, the education expansion will add about ha If a million persons to the Geman labor force in 2060 (when compared with a scenario with constant education by sex and age group), compensating 9 percent of the negative demographic effect (a mounting to almost 5.5 million persons). This positive educ ation effect increa ses if we extend the horizon of the projection as the impact of additional education on laborforce participation is strongest towa rds the end of employment careers (cf. Section 5.2.2 a s well as Horvath et al., 2021). In the United States, we project the educational expansion to add about 2 million persons to the workforce in 2060, compared to a demographic effect of a bout 24 million workers.

The pension reform effect shows how, in addition to the education effect, the size of the labor force changes due to inc reased minimum early and regular retirement a ge. For Gemany, our model assumes a one-time increase in regularpension age in 2030 from 65.8 years in 2020 to 67 years. Early pension age is assumed to remain constant, at 63 years. For the United States, we assume the full-benefit retirement age to increase from 66 years and 2 months for people bom in 1955, and to gradually rise to 67 for those bom in 1960 or later. Ea rly retirement benefits will continue to be available at age 62 (although the benefit amount will be reduced over time). The projected effect from pension reforms is limited to the older a ge groups, persons 65 and above, and a lways positive. The baseline results project an increase by 0.4 million workers in the size of the labor force between 2020 and 2060 in Gemany and 0.8 million workers in the United States. 
Figure 10: Decomposition of changes in labor force between 2020 and 2060 United States

- Population effect $\quad$ Education effect $\quad$ Pension effect $\quad$ Total change in LFP

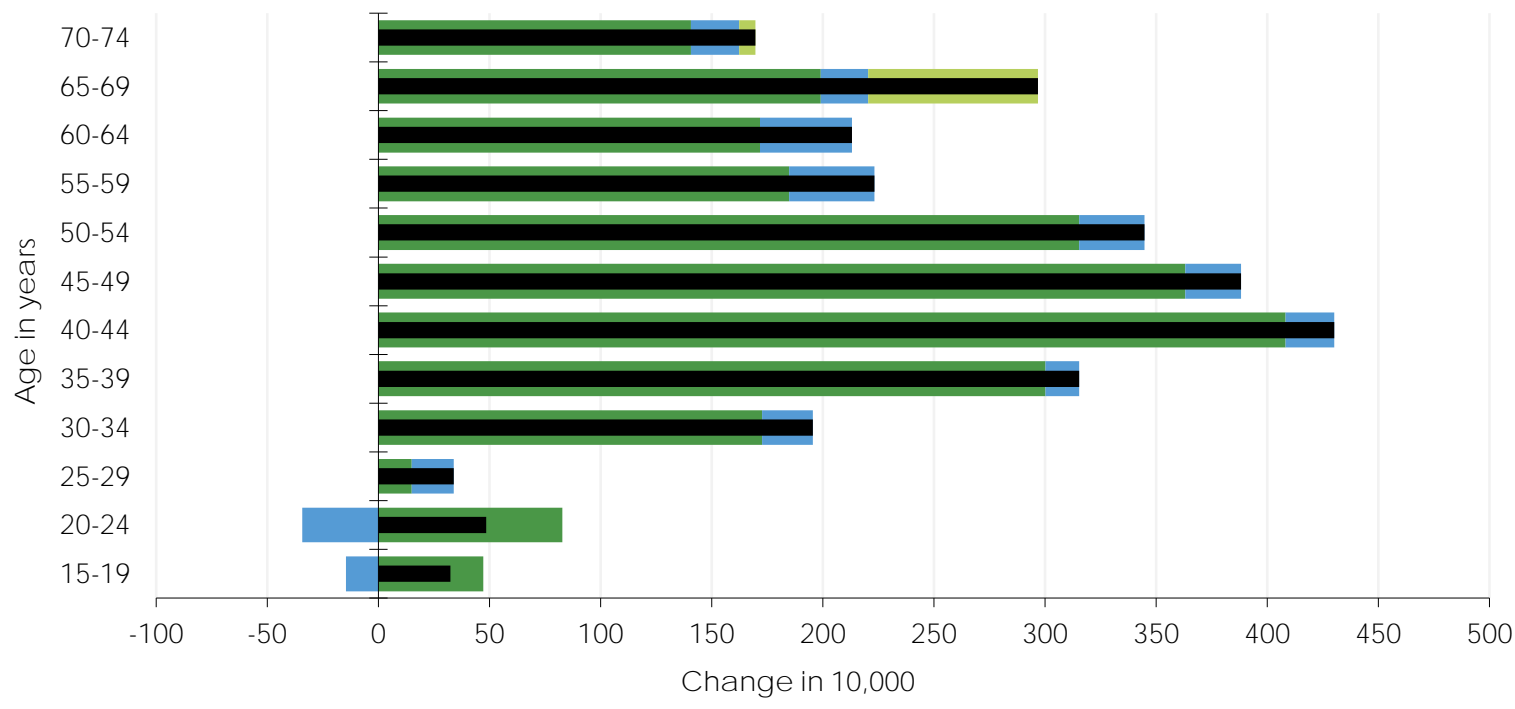

Germany

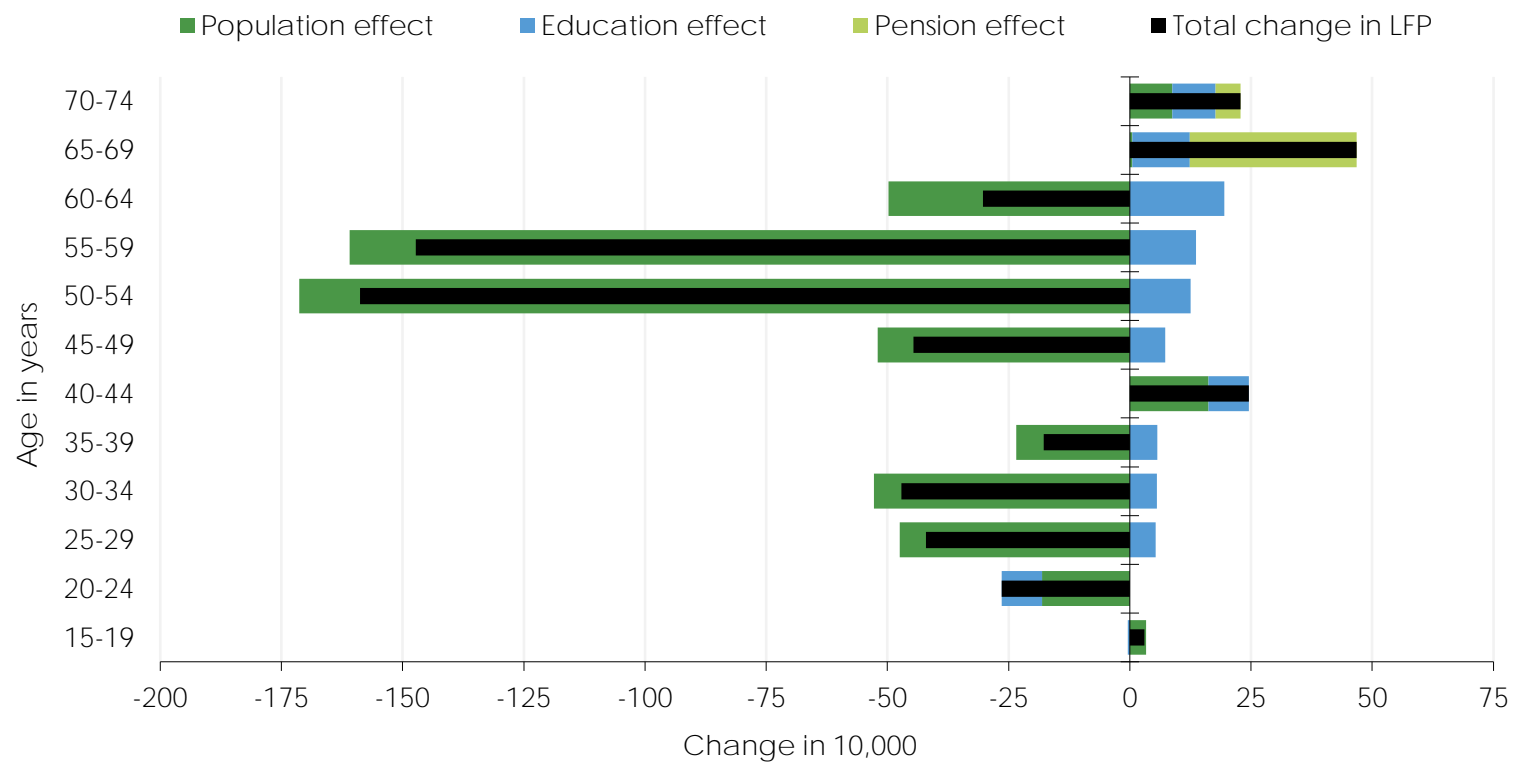

S: WIFO. 


\subsection{Scenarios}

\subsubsection{Scenario description}

To assess how polic y reforms a ddressing education and health might affect labor force participation in the coming decades, we select a series of what-if scenarios. We first examine the implic ations of improvements in the educational structure of the population. Secondly, we use sc enarios which address the impact of health on labor force participation.

For the first set of sc enarios of educa tional reforms, we choose scenarios with pronounced shifts between educational levels. These affect, by assumption, 25 percent of the selected educational groups. The reason for such a strong ad-hoc assumption is that changes in individual educational levels have only small effects on overall participation rates, especially in the short run, as additional years of schooling lead to a lock-in effect that first reduc es labor force participation. Also, shifts between single education levels might affect only a small fraction of the population. For example, if only 10 percent of a cohort have little formal education, a policy that successfully moves 1 percent of those to the next higher attainment level would affect only 0.1 percent of the cohort. In our scenarios of higher transitions between two adjacent educational levels, we do not change the proportions of people at the remaining (higher) levels. For example, when we assume that a polic y moves 25 percent of persons from the first to the sec ond ed uc ation level (i.e. from "below high school" to "high sc hool"), this only inc rea ses the size of the second education group, and leaves the higher education groups unaffected. These scenarios are partic ula rly helpful in gauging and comparing the effects of specific forms of educ ational expansion.

The fourth scenario consists of a combination of the other three scenarios. It provides a benchmark for the effects that we can expect due to a substantial improvement of future cohorts' educational atta inment. The resulting four scenarios are described in Table 1.

\section{Table 1: Description of scenarios for inc reased educational attainment}

\begin{tabular}{|c|c|c|c|c|}
\hline \multirow[t]{2}{*}{$\begin{array}{l}\text { Education } \\
\text { scenario }\end{array}$} & \multirow[t]{2}{*}{ Description of educational shift } & \multirow{2}{*}{$\begin{array}{l}\text { Affected share of the } \\
\text { respective education } \\
\text { group (birth cohorts from } \\
2010 \text { onwards) }\end{array}$} & \multicolumn{2}{|c|}{$\begin{array}{l}\text { Affected share of the total } \\
2010 \text { birth cohort }\end{array}$} \\
\hline & & & United States & Germany \\
\hline S1 & $\begin{array}{c}\text { From level } 1 \text { (below high school/ISCED 0-2) to level } 2 \\
\text { (high school/ISCED 3) }\end{array}$ & $25 \%$ & $1.7 \%$ & $2.2 \%$ \\
\hline S2 & $\begin{array}{c}\text { From level } 2 \text { (high school/ISCED 3) to level } 3 \text { (some } \\
\text { college/ISCED 4) }\end{array}$ & $25 \%$ & $6.3 \%$ & $6.8 \%$ \\
\hline S3 & $\begin{array}{c}\text { From level } 3 \text { (some college/ISCED 4) to level } 4 \\
\text { (university/ ISCED 5+) }\end{array}$ & $25 \%$ & $7.6 \%$ & $4.1 \%$ \\
\hline S4 & From each educational level to the next-higher one & $25 \%$ & \multicolumn{2}{|c|}{ All of the above combined } \\
\hline
\end{tabular}

S: WIFO. 
Note that, because of the differences between educational groups' sizes, an equal improvement in the proportion of persons who atta in the next educational level will result in different sizes of the groups who advance between education levels. Moreover, the projected effects of an educational expansion might differ considerably, depending on the simulation horizon, and on the targeted age groups. To provide a comprehensive account of the results and to increase comparability, we present the results in different forms: In a first step, we present the labor force outcomes from the viewpoint of one cohort (birth year 2010). The effects are displayed in tems of (1) changes along the life-cycle, (2) cumula tive changes over the life-cycle, and (3) standa rdized effectsscaled by the number of a dditional years of schooling (above the age of 15). In a second step, the aggregated effects for the whole population are examined for a selected simulation horizon.

The what-if scenarios of the second type of reforms highlight the potential effect of health improvements as well as of polic y changes that improve the la bor market integration of workingaged persons with health limitations. The two scenarios are described in Table 2 . The first health scenario (S5) addresses the question of how the health status of the working-age population will develop over time. The baseline demographic projections consider changes in life expectancy over time, but they do not account for possible improvements in terms of healthy life years. Although there is uncertainty regarding future developments and the extent to which we will experience a "compression" or "expansion" of morbid ity, evidence suggests that hea thy life years and working life expectancy have been increasing (Weber and Loichinger, 2020). In our baseline scenario, the negative impact of demographic aging on the health composition of the workforce is thus likely overstated. In scenario (S5) we therefore assume that increases in life expectancy lead to a proportional extension of healthy life years in the working-age population. For instance, if the life expectancy increases by five years, the group of those aged 60 to 64 years is attributed the same health struc ture that waspreviously displayed by those aged 55 to 59 years.

Table 2: Description of health scenarios

\begin{tabular}{lr}
$\begin{array}{l}\text { Health } \\
\text { scenario }\end{array}$ & Description of health improvement \\
\hline S5 & Increase in life expectancy leads to a proportional extension of healthy life years in the working- \\
age population
\end{tabular}

S: WIFO.

In the sec ond health-related scenario (S6), we highlight the potential of policiesto improve the labor market inclusion of ind ividuals with poor health. Ta ble 2 compa res the labor force partic ipation rates of workers with poor health in the U.S., Germany and three benchmark countries, using the CPS and EU-SILC data on which our dynamic mic rosimulation modeling is based. We select the Netherlands, Switzerland, and Sweden as benchmark countries because of their intense reform activities in sickness and disability policies (cfr. Section 2.2.3). Workers with poor health are defined as those in the bottom tertile of the health distribution. (We calculate a 
synthetic health measure for a more accurate comparison of the health distributions.) As we can see, the participation rates of workers with health problems, as well as the differential between workers in good or poor health, vary considerably. The United States have the lowest participation rates and the la rgest health-related partic ipation gaps, with the exception of the age group 65 to 69, where the share of labor market participants is higher in the U.S. than in the other countries. While the Netherlands have values that are similar to those in Gemany, Switzerland, and, in partic ular, Sweden have higher activity rates and smaller health-rela ted gaps.

Ta ble 3: Partic ipation rates of persons with poor health, United States and Germany compared to selected countries

\begin{tabular}{|c|c|c|c|c|c|c|c|c|c|c|}
\hline & & & Wome & & & & & Men & & \\
\hline Age in years & US & $\mathrm{DE}$ & $\mathrm{CH}$ & $\mathrm{NL}$ & SE & US & $\mathrm{DE}$ & $\mathrm{CH}$ & $\mathrm{NL}$ & SE \\
\hline \multicolumn{11}{|c|}{ Labor force participation rates of those in poor health (in \%) } \\
\hline 50 to 54 & 61.6 & 73.0 & 82.6 & 60.4 & 84.9 & 71.6 & 81.4 & 89.9 & 71.9 & 87.5 \\
\hline 55 to 59 & 62.6 & 70.4 & 70.0 & 58.7 & 84.5 & 62.6 & 80.0 & 84.1 & 67.2 & 90.0 \\
\hline 60 to 64 & 63.6 & 55.3 & 56.2 & 40.6 & 69.5 & 50.8 & 57.6 & 68.0 & 52.6 & 69.1 \\
\hline 65 to 69 & 64.6 & 1.9 & 5.4 & 8.2 & 13.9 & 30.6 & 1.8 & 22.4 & 19.9 & 16.8 \\
\hline \multicolumn{11}{|c|}{ Difference between good and poor health (in percentage points) } \\
\hline 50 to 54 & 22.9 & 15.0 & -1.8 & 17.8 & 5.2 & 23.7 & 13.0 & 4.2 & 17.2 & 6.3 \\
\hline 55 to 59 & 23.9 & 11.9 & 5.5 & 13.1 & 3.9 & 30.5 & 9.4 & 6.9 & 20.3 & 2.9 \\
\hline 60 to 64 & 24.9 & 8.3 & 2.1 & 7.7 & 5.2 & 28.5 & 12.8 & 6.5 & 17.6 & 10.2 \\
\hline 65 to 69 & 25.9 & 1.3 & 4.4 & 0.9 & 1.6 & 22.8 & 2.7 & -0.3 & -1.7 & 4.4 \\
\hline
\end{tabular}

S: WIFO calculations based on CPS data for the U.S. and EU-SILC data for the European countries.

We use Sweden as a benchmark in scenario S6 and assume that up to 2060 the impact of impa ired health on laborma rket partic ipation in the U.S. and Germany converges to observed differences by health status in Sweden of 2020.

\subsubsection{Scenario results}

\subsubsection{Educ ation scenarios}

\section{Results from the perspective of a single cohort (year of birth 2010)}

Figure 11 shows how the number of laborforce partic ipants of the cohort of 2010 changesover the life-cycle in the four different scenarios compared to our baseline scenario. The shift to higher educational attainment reduces labor force participation at youngerages because of the educational lock-in effect. A positive effect on the number of labor force participants emerges between the age of 20 and 27, depending on the type of educational expansion implied by the scenario. Overall, the qua ntitative impacts of these educational expansions are moderate. The Geman cohort consists of a bout 900,000 persons and, depending on the age, we observe increases in the labor force of up to 18,000 persons, i.e., roughly 2 percent of the 
cohort. The magnitude is similar in the U.S., where, starting from a birth cohort with about 4.1 million persons, we observe the maximum in scenario S4 with a projection of about 150,000 additional persons in the labor force at the age of 65 (corresponding to an increase of 3.5 percent).

Figure 11: Change in the labor force of the $\mathbf{2 0 1 0}$ birth cohort, by education scenario United States, deviation from the baseline scenario

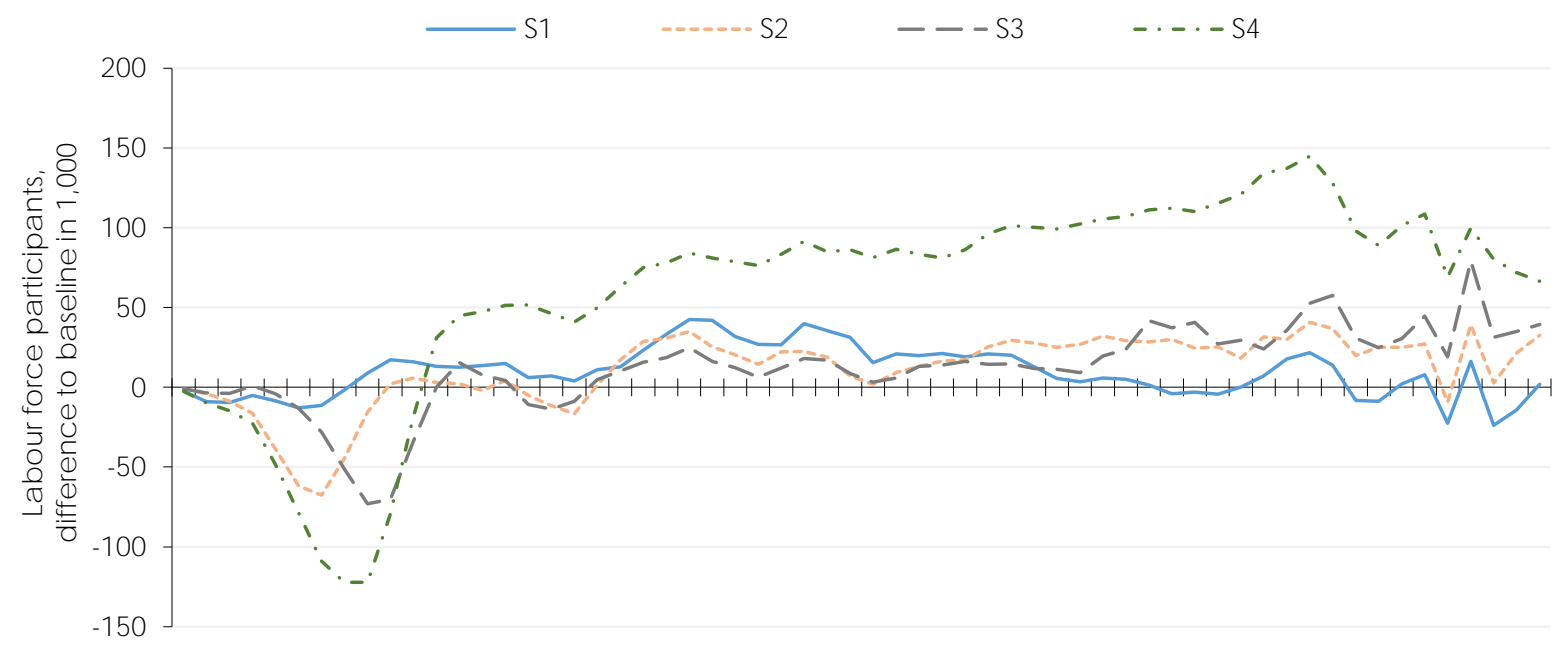

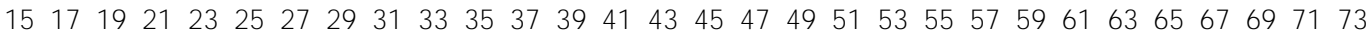
Age in years

Germany, deviation from the baseline scenario

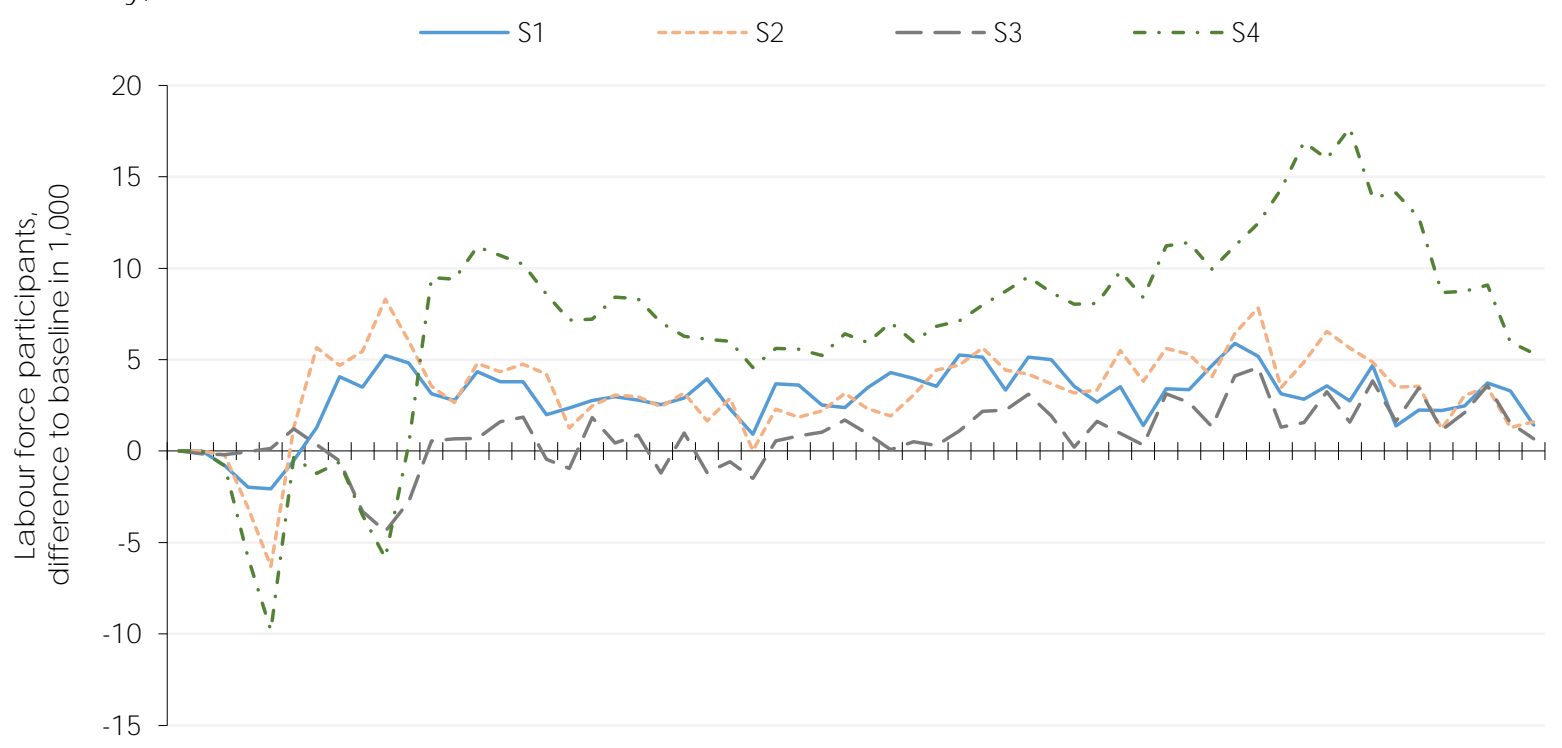

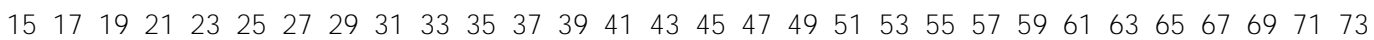
Age in years

S: WIFO, mic roWELT. - Scenarios S1 to S4, as described in Table 1. Moving a verages over three single year age groups. 
Table 4 displays the cumula tive effects of the scenarios for the 2010 birth cohort over the entire working life (age 15 to 74 years and different age groups). In the first scenario (S1), the number of person-years in the labor force increases by 0.5 percent in Germany (corresponding to an increase of about 176,000 person-years) and 0.3 percent in the U.S. (corresponding to about 600,000 person-years). The effects of the second scenario (S2) are slightly stronger, but otherwise similar, in both countries. (It is important to note that scenano $\mathbf{S 2}$ affects a much larger share of the cohort than scenario S1.) The third scenario (S3) leads to a more modest effect in Germany than in the United States. This is because of the small difference in participation rates between high school graduates with a dual education compared to university graduates in Germany. In the U.S., on the other hand, university graduates are more attached to the labor market than persons with (some) college education. The absolute effects of scenarios S2 and S3 in the United States and S2 in Germany are larger than those of scenario S1, but we have to bear in mind that S2 and S3 involve much higher shares of the population than S1 (cfr. Table 1).

In the fourth sc enario (S4), the labor force increa ses cumulatively by 418,000 person-years (1.1 percent) in Germany and 3.7 million person-years ( 2 percent) in the United States. In almost all scenarios, the most substantial effects are measured for the older age groups. These age groups currently have a below-a verage level of labor force participation, particularly in Germany, and frequently exit into retirement early.

Ta ble 4: Cumulative changes in labor force participation, by education scenario (S1 to S4) United States and Germany, deviation from the baseline scenario

\begin{tabular}{|c|c|c|c|c|c|c|c|c|}
\hline \multirow[t]{4}{*}{ Scenario } & \multicolumn{8}{|c|}{ Labor force participation over the life course } \\
\hline & \multicolumn{4}{|c|}{ US } & \multicolumn{4}{|c|}{ DE } \\
\hline & \multicolumn{2}{|c|}{ Age 15 to 74} & \multicolumn{2}{|c|}{ Age 60 to 74} & \multicolumn{2}{|c|}{ Age 15 to 74} & \multicolumn{2}{|c|}{ Age 60 to 74} \\
\hline & Years & $\ln \%$ & Years & $\ln \%$ & Years & $\ln \%$ & Years & $\ln \%$ \\
\hline $\mathrm{S} 1$ & 596,346 & 0.3 & 27,461 & 0.1 & 175,616 & 0.5 & 49,490 & 1.0 \\
\hline S2 & 681,103 & 0.4 & 307,355 & 1.5 & 198,035 & 0.5 & 61,397 & 1.2 \\
\hline S3 & 725,572 & 0.4 & 483,926 & 2.4 & 55,206 & 0.1 & 35,733 & 0.7 \\
\hline S4 & $3,663,733$ & 2.0 & $1,219,774$ & 6.1 & 417,734 & 1.1 & 177,016 & 3.6 \\
\hline
\end{tabular}

S: WIFO, mic roWELT. - Scenarios S1 to S4, as described in Table 1. Years a re person-years.

Since the four scenarios imply tra nsitions between educational levels of differently-sized population groups, Figure 12 provides an overview of the standardized effects. The standardized effects are obtained by dividing the total changes in labor force participation displayed in Table 4, by the additional years of schooling that result from the respective scena rio. The effects can be interpreted a na logously to a n elasticity, expressing the relative change in labor market outcome (labor force participation in years) for a 1-year-change in the number of years of schooling in the population (above age 15). Both the years-of-schooling and the labor market participation are measured cumulatively over the projection period. To highlight that the effectsa re more pronounced towards the end of the working life, where laborforce participation is presently low, we show the effects separately for ages 15 to 74 and the ages 60 to 74 . In all scenarios and in both countries, the relative effect of additional schooling is stronger towards 
the end of the working life than the effect on the entire working life (age 15 to 69). The first scenario, which increases the number of persons who attain high school education, has the strongest relative effects on participation over all age groups. For each additional year of schooling at the high sc hool (ISCED 3) level, la borforce partic ipation inc reases by 0.23 percent in the United States and 0.21 percent in Gemany. This compa ratively large effect results from the fact that labor force participation rates among those with low education (ISCED 0-2 or "below high school") a re lowest among all education groupsat most ages. Shifting people from intermediate to higher education levels results in more modest increases in labor force partic ipation, as the differences in labor force partic ipation rates are less pronounced compared to the lowest education level. (See also Figure 7.)

Figure 12: Standardized labor market effects, by education scenario (S1 to S4)

United States and Germany, deviation from the baseline scenario

age 15 to 74 Age 60 to 74
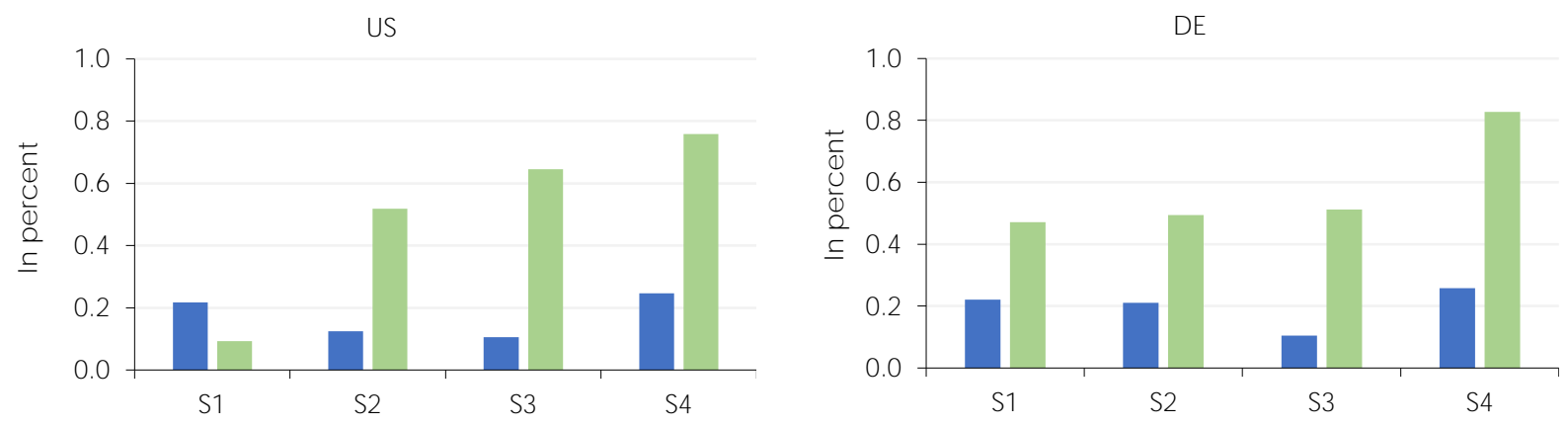

S: WIFO, mic roWELT. - Scenarios S1 to S4, as described in Table 1.

\section{Presentation from a macroeconomic perspective (target years 2060 and 2080)}

This section presents the overall effects of the education scenarios (affecting all cohorts bom 2010 and later) for individual target years. Conceming changes in education and their labor market effects, our main projection horizon until 2060 is comparatively short. In 2060, most of the cohort of 2010 will have spent fewer than 30 years on the labor market and will still have a part of their working life ahead of them. For this reason, Figure 13 and Figure 14 provide an overview of the results of the different scenarios, both for 2050 and 2080. 2080 is the year when the birth cohort 2010 will have tumed 70 years of a ge and most will have completed their working life. The first two graphs (Figure 13) show the changes in absolute terms. The graphs in Figure 14 show the effects relative to the corresponding populations in the baseline scenario for the years 2060 and 2080. The lack of effects for scenario S3 in Gemany is due to the small difference in participation rates in this country between high school graduates with a dual education and university graduates. 
Figure 13: Total absolute effects in 2060 and 2080, by education scenario (S1 to S4)

United States and Gemany, deviation from the baseline scenario

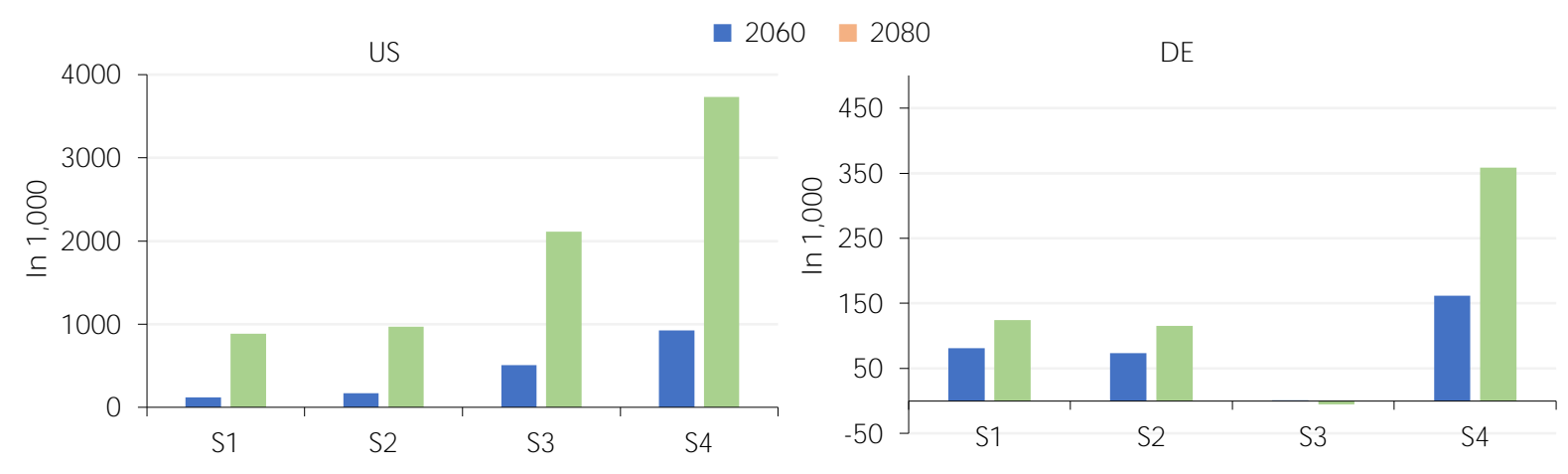

S: WIFO, mic roWELT. - Scenarios S1 to S4, as described in Table 1.

The results show that a sizeable (further) educational expansion will ha ve only a limited impact by 2060 . The effects are stronger when we foc us on the year 2080 . We can expect a sizeable educational expansion (S4) to increase the Geman laborforce by approximately 350,000 persons in 2080 compared to the baseline scenario. This number represents a modest increase compared to the total laborforce projected in the baseline sc enario ( +0.9 percent). However, compared to the labor force decline projected in our baseline (about 4.5 million fewer labor force partic ipants by 2080), the effect is non-neg ligible (a round 7.5 percent of the total dec line in laborforce participants). While the education expansion in the baseline scenario adds approximately 920,000 persons to the labor force in 2080 , the number increa ses to more than 1.25 million in scenario (S4). Education effects therefore compensate for around 15 percent of the demographic-induced decline in the number of labor force participants in the baseline and a round 20 percent in the education scenario (S4). In the United States, scenario S4 corresponds to an increase in the laborforce by 3.7 million workers in 2080, i.e. an increa se of +1.9 percent. 
Figure 14: Total relative effects in $\mathbf{2 0 6 0}$ and 2080, by education scenario (S1 to S4)

Germany, deviation from the baseline scenario

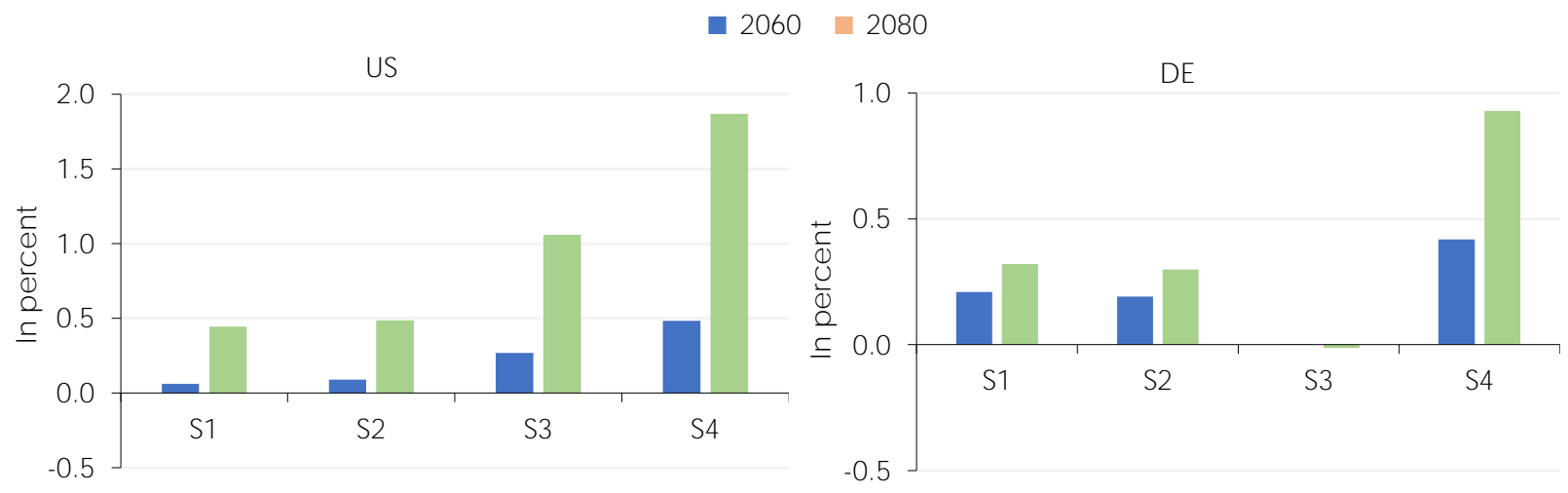

S: WIFO, mic roWELT. - Scenarios S1 to S4, as described in Table 1.

\subsubsection{Health scenarios}

Figure 15 presents the results from the health-related scenarios S5 and S6. Unlike in the case of the education scenarios, which aim at changes affecting specific cohorts, a separate presentation of cohort-specific and total effects is not meaning ful here. Figure 15 displays the projected effects of the health scenarios in terms of labor force partic ipation, relative to the baseline results. Scenario S5, where we assume a "sloweraging" of the population and thus improvements in health status that mirror the extension of life expectancy, has only a small qua ntitative impact, which increases slightly over time. It should be stressed, however, that the assumption behind this scenario implies a sort of "dynamic equilibrium" in the development of life expectancy and healthy working life expectancy. This scenario is more optimistic than our ba seline scenario, but it can still be qualified as cautious when compared with possible scenarios with more substantial improvements in population health.

Figure 15: Change in the labor force, by health scenario

United States and Gemany, deviation from the baseline scenario
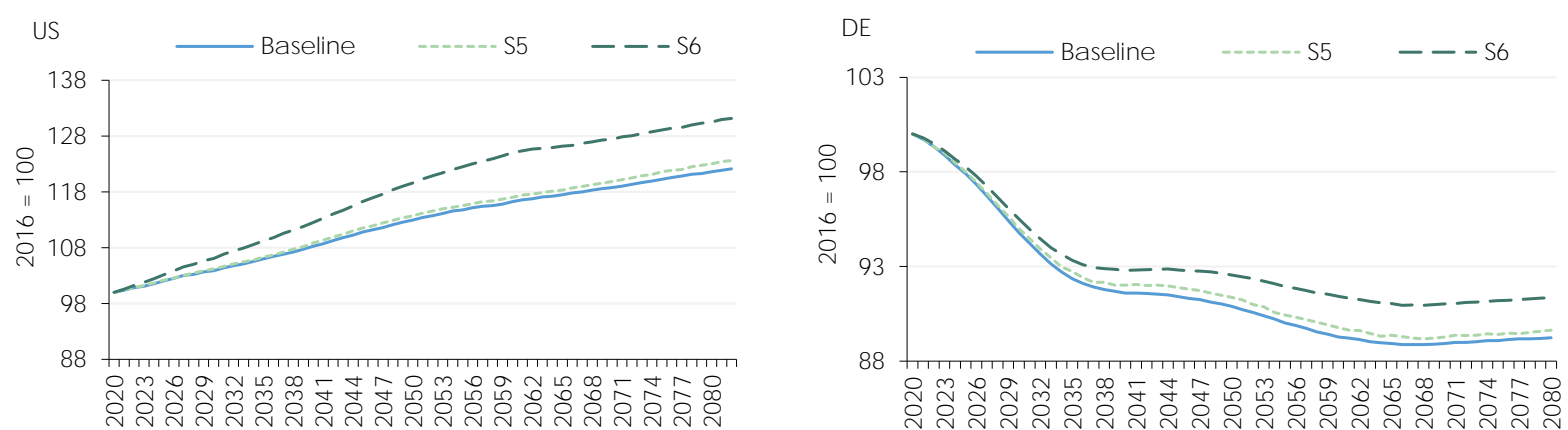

S: WIFO, mic roWELT. - Scenarios S5 and S6, as described in Table 2. 
Scena rio S6, on the otherhand, with Sweden asthe benc hmark for the la bormarket integration of working-aged persons in the bottom tertile of the health distribution, shows that a reduction of the health gap in labor force participation can have a substantial impact on labor force dynamic s. Figure 16 and Figure 17 provide an overview of the total and relative effects associated with the two scenarios in 2060 and 2080 . If Gemany were to approach partic ipation pattems currently displayed by Sweden, this would add a bout 1.1 million personsto the laborforce by 2060 ( +2.8 percent) and about 1.0 million by 2080 ( +2.7 percent) compared to the baseline scenario described in Section 5.1, additionally compensating for around 17 to 21 percent of the decline implied by demographic aging. The effects of reducing the health gap in partic ipation rateswould be even larger in the United States. Our mic rosimulation results ind ic a te that scenario S6 would add 14.9 million persons to the workforce in 2060 (corresponding to +6.6 percent compared to the baseline) and 15.3 million persons in 2080 ( +7.6 percent). The effects are so strong, because currently health gaps in labor market outcomes are more pronounced in the U.S. than they are in Germany.

Figure 16: Absolute effects in $\mathbf{2 0 6 0}$ and 2080, health scenarios (S5 and S6)

United States and Gemany, deviation from baseline scenario

$2060 \square 2080$
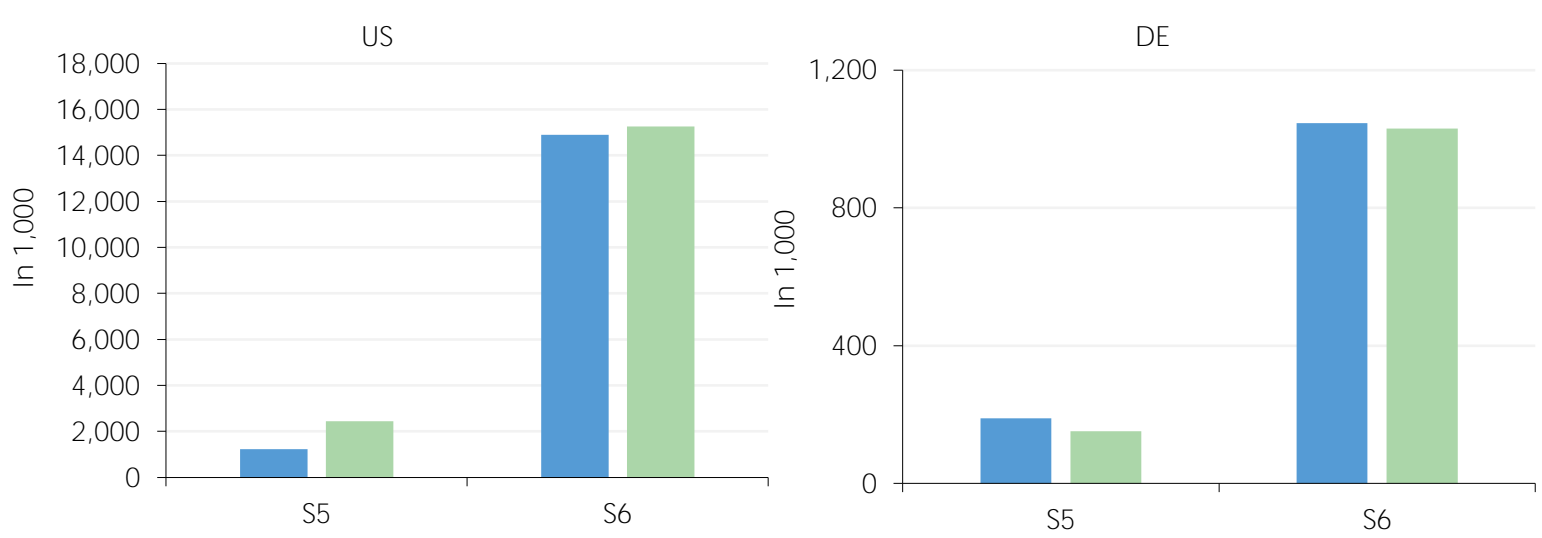

S: WIFO, mic roWELT. Scenarios S5 andS6, as described in Table 2. 
Figure 17: Relative effects in $\mathbf{2 0 6 0}$ and 2080, health scenarios (S5 and S6)

United States and Germany, deviation from baseline scenario

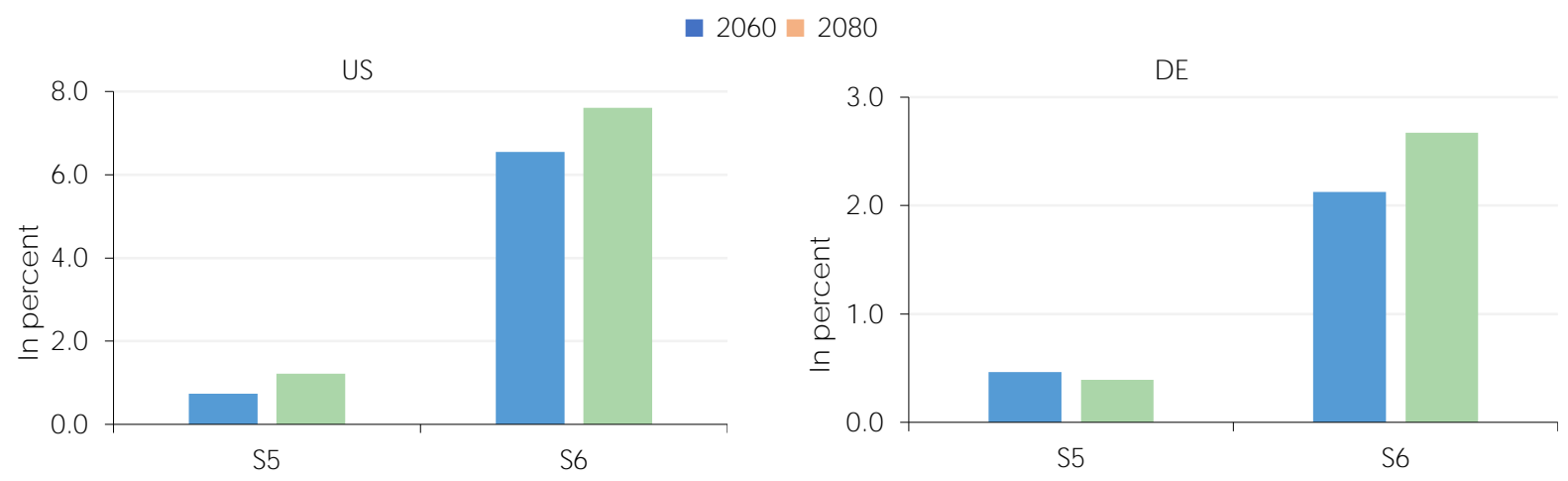

S: WIFO, mic roWELT. Scenarios S5 and S6, as described in Table 2.

\section{Summary}

We studied the effects of education and health reforms on the U.S. labor force with a dyna mic mic rosimulation until 2060. The mic rosimula tion explic itly models the deteminants of labor force partic ipation using a large number of simulated individua ls in continuous time. It allows to quantify how changes in individual characteristic s affect labor force participation through direct and indirect processes. Projected changes in labor force partic ipation can be decomposed into underlying factors, such aspopulation aging orchanges in the population's education structure. In our polic y a nalyses, we foc us on shifts in the educational structure and on polic ies that improve the labor market integration of working-aged persons with health limitations. We contrast the projected effects with projection results for Gemany.

Both the U.S. and Gemany are expected to undergo demographic aging, but their current demogra phic circumstances differ starkly. This has strong implic a tions for their la bor force developments. According to our mic rosimulation, the U.S. labor force will, despite population aging, increase by 16.2 percent in the age groups 15 to 74 (correspond ing to 25.2 million workers) between 2020 and 2060, while Germany will experience a decline by 10.7 percent (4.4 million workers). In these baseline projections, improvements in the education structure will add about two million persons to the U.S. laborforce and about half a million persons to the Geman laborforce by 2060.

In the what-if-scenarios, we examine the implications of improvements in the educational struc ture of the population and of polic ies which address the health dimension of labor force participation. Of the what-if-sc ena rios that foc us on educ ation, relative to the number of additional school years, inc rea sing the number of persons who achieve high-school education has the strongest positive impact on labor force partic ipation. Since the number of people with less than high school educ ation is comparatively small, however, the absolute effect of educational expansion targeting only this group is modest. Shifting people from intermediate to higher educ ation levels increases the laborforce partic ipation in higher age groups but 
this inc rea se is partially offset by lock-in effects at younger ages. In a lmost a ll education scenarios, the most substantial effects are measured at the end of working careers when labor force partic ipation is currently lowest. Accordingly, the effects of an (additional) educational expansion take time to materialize. A scenario for a broad educ ational expansion, moving 25 percent of persons in each educ ational group to the next-higher educ ational level, adds slightly less than 1 million workers to the U.S. labor force in 2060 (compared to our baseline, which already includes a rise in educ ation levels). This effect is stronger when we extend the projection horizon, a dding about 3.7 million workers to the U.S. labor force in 2080 (compared to our baseline).

Our projections highlight that improvements in the labor market integration of people with health limitations provide a particularly promising a venue to increase labor force participation and thus cushion the negative economic effects of demographic aging. If the health gap in participation rates in the U.S. were similar to Sweden's, the laborforce in 2060 would be stronger by about 14.9 million persons than in our baseline projections. The results suggest that health promotion and measures to prolong working life should be the comerstones of any strategy to mitigate the impact of demographic ageing on the labor market and the economy. At the same time, there is scope for polic y-makers to address the negative impact of health problems on labor market outcomes and to foster the labor market inclusion of workers with both temporary and perma nent health impa iments.

The mic rosimulation for Gemany, but also those for other European countries which a re illustrated in the accompanying tec hnic al report (Amann et al., forthcoming), shows that the effects of educational expansion and improved population health are larger in terms of employment and hours worked, than on labor force partic ipation. The effects a re larger because low educ ational atta inment and health limitations inc rea se the risk of unemployment and of underemployment, compared to higher educ ation and good health. Thus, most what-if-scenarios lead to a greater increase in the number of employed persons and in the number of hours worked, than in the number of labor force partic ipants. 


\section{Literature}

Aaronson, Daniel, Luojia Hu, Arian Seifoddini, and Daniel G. Sullivan (2014). Declining labor force participation and its implic a tions for unemployment and employment growth. Economic Perspectives, 38(4).

Abraham, Katherine G., and Melissa S. Keamey (2020). Explaining the decline in the US employment-to-population ratio: A review of the evidence. J oumal of Ec onomic Literature, 58(3), 585-643.

Amann, J ohannes, René Böheim, Tom Horvath, Thomas Leoni, and Martin Spielauer (forthcoming). The mic roWELT-US Mic rosimulation Model for Projections of the US Labor Force Participation Accounting for Education and Health, Technical Report - Project NB21-17.

Becker, Gary S. (1976). The Economic Approach to Human Behaviour. University of Chicago Press, Chicago and London.

Bellmann, Lutz, and Stephanie Prümer (2021). Double qualifications and gender: The case of Gemany. LASER Discussion Papers, No. 127. Nuremberg, Gemany.

BLS (U.S. Bureau of Labor Statistics) (2021). Employment Projections: Calculation. Handbook of Methods. https://www.bls.gov/opub/hom/emp/calculation.htm [retrieved 2021-07-26].

Board of Trustees (2020). The 2020 Annual Report of the Board of Trustees of the Federal Old-age and Survivors Insurance and Federal Disability Insurance Trust Funds. https://www.ssa.gov/oact/tr/2020/tr2020.pdf [retrieved 202109-10].

Böheim, René, and Thomas Leoni (2018). Sic knessand disa bility policies: Reform paths in OECD countries between 1990 and 2014. Intemational J oumal of Social Welfa re, 27(2), 168-185.

Börsch-Supan, Axel, Agar Brugiavini, and Enrica Croda, E. (2009). The role of institutionsand health in European pattems of work and retirement. J oumal of European Social Policy, 19(4), 341-358.

Browne, J ames, and Hervig Immervoll (2017). Mechanic s of replacing benefit systems with a basic income: comparative results from a mic rosimulation approach. The J oumal of Economic Inequality, 15(4), 325-344.

CBO (Congressional Budget Office) (2021A). Long-Term Budget Outlook, March 2021.

CBO (Congressional Budget Office) (2021B). Long-Term Economic Projections. Supplement to CBO's 2021 Long-Term Budget Outlook. https://www.cbo.gov/data/budget-economic-data [retrieved 2021-09-10].

Crimmins, Eileen M., and Hiram Beltrán-Sánchez (2011). Morta lity and morbidity trends: Is there compression of morbidity? J oumals of Gerontology Series B: Psychologic al Sc iences and Social Sc iences, 66(1), 75-86.

Current Population Survey (2019). Annual Social and Economic Supplement. https://www.census.gov/content/census/en/data/ta bles/2019/demo/educational-atta inment/cps-detailed-ta bles.html [retrieved 2021-09-10].

Cutler, David M., and Adriana Leras-Muney (2010). Understanding differences in health behaviors by education. J ournal of Health Ec onomics, 29(1), 1-28.

Czaja, Sara J. (2020). Setting the stage: Workplace and demographic trends. In Czaja, Sara J., Joseph Sharit, and J acquelyn B. J ames (Eds.), Current and Emerging Trends in Aging and Work, Springer., 3-11.

Del Boca, Daniela (2002). The effect of child care and part time opportunities on participation and fertility decisions in Italy. J oumal of Population Ec onomics, 15(3), 549-573.

Dubina, Kevin S., J a nie-Lynn Kim, Emily Rolen, and Michael J . Rieley (2020). Projections overview and highlights, 201929. Monthly Labor Review, U.S. Bureau of Labor Statistics, September 2020. https://doi.org/10.21916/mlr.2020.21 [retrieved 2021-09-06].

Eide, Eric R., and Mark H. Showalter (2011). Estimating the relation between health and education: What do we know and what do we need to know?. Economics of Education Review, 30(5), 778-791.

European Commission (2017). The 2018 ageing report: Underlying assumptions and projection methodologies. Institutional Paper 65, Public ations Office of the European Union. Luxembourg.

European Commission (2018). The 2018 ageing report: Economic and budgetary projections for the 28 EU member states (2016-2070). Institutional Paper 79, Public ations Office of the European Union, Luxembourg.

European Commission (2020). The 2021 ageing report: Underlying assumptions and projection methods. Institutional Paper 142, Public ations Office of the European Union, Luxembourg. 
European Commission (2021). The 2021 ageing report: Economic and budgetary projections for the EU member states (2019-2070). Institutional Paper 148, Public a tions Office of the European Union. Luxembourg.

Favreault, Melissa M., Karen E. Smith, and Richard W. Johnson (2015). The dynamic simulation of income model (DYNASIM). Washington, DC: Urban Institute.

Femández, Raquel, Fogli, Alessandra, and Claudia Olivetti (2005). Mothersand sons: Preference formation and female labour force dynamics. The Quarterly J oumal of Economics, 119(4), 1249-1299.

Folbre, Nancy (1994). Children as public goods. American Economic Review, 84(2), 86-90.

Gál, Róbert I., András Horváth, Gábor Orbán, and Gijs Dekkers (2009). Monitoring pension developments through mic ro socio-economic instruments based on individual data sources. TARKI Social Research Institute, Budapest, https://ec .europa .eu/social/BlobServlet? docld =2366\&langld=en [retrieved 2021-09-06].

Geiger, Baumberg Ben, René Böheim, and Thomas Leoni (2019). The growing American health penalty: Intemational trends in the employment of older workers with poor health. Social Science Research, 82, 18-32.

Goldin, Claudia, and Lawrence F. Katz (2009). The Race Between Education and Technology, Harvard University Press, Cambridge, Massa chusetts.

Grossman, Michael (2015). The relationship between health and schooling: What's new?, National Bureau of Economic Research (NBER), Working Paper 21609.

Hemmings, Philip, and Christopher Prinz (2020). Sickness and disability systems: Companing outcomes and policies in Norway with those in Sweden, the Netherlands and Switzerland, OECD Economics Department Working Papers No. 1601.

Horvath, Thomas, Serguei Kaniovski, Thomas Leoni, Martin Spielauer, and Thomas Ur (2021). The impact of education and health on labour force participation and the macroeconomic consequences of ageing. Bertelsmann Stiftung, Gütersloh.

Jaumotte, Florence (2003). Labour force participation of women: Empirical evidence on the role of policy and other determinants in OECD countries. OECD Economic Studies, 2/2003, 51-108.

Koning, Pierre, and Maarten Lindeboom (2015). The rise and fall of disability insurance enrollment in the Netherlands. J oumal of Economic Perspectives, 29(2), 151-72.

Krueger, Alan B. (2017). Where have all the workers gone? An inquiry into the decline of the U.S. laborforce participation rate. Brookings Papers on Ec onomic Activity Fall 2017, 1- 59.

Laplagne, Patrick, Maurice Glover, and Anthony Shomos (2007). Effects of health and education on labor force participation. Australian Govemment Productivity Commission Staff Working Paper, Melboume.

Leoni, Thomas (forthcoming). Graded work, the activation of sick-listed workers and employer participation in continental Europe. Social Policy and Society. https://doi.org/10.1017/S1474746420000639 [retrieved 2021-09-06].

Lundborg, Petter (2013). The health retums to schooling - what can we leam from twins? Joumal of Population Economics, 26(2), 673-701.

Marois, Guillaume, and Arda Aktas (2021). Projecting health-ageing trajectories in Europe using a dynamic microsimulation model. Scientific Reports 11 (1).

Marois, Guillaume, Patrick Sa bourin, and Ala in Bélanger (2019). How reducing differentials in education and laborforce participation could lessen workforce decline in the EU-28. Demographic Research, 41(6), 125-158.

Medina, Lauren, Shannon Sabo, and J onathan Vespa (2020). Living longer: Historical and projected life expectancy in the United States, 1960 to 2060, Report P25-1145, US Census Bureau. https://www.census.gov/content/dam/Census/library/public ations/2020/demo/p25-1145.pdf [retrieved 2021-09-06].

Mincer, J a cob (1974). Schooling, Experience, and Eamings, Columbia University Press, New York.

Montes, J oshua (2018). CBO's Projection of Labor Force Participation Rate, Working Paper 2018-04, Working Paper Series Congressional Budget Office Washington, D.C.

Momis, Zachary (2016). Constructing the need for retrenchment: Disa bility benefits in the United Statesand Great Brita in. Policy \& Politics, 44(4), 609-626.

OECD (2003). Transforming Disa bility into Ability. OECD Publishing, Paris.

OECD (2010). Sic kness, disa bility and work. Breaking the ba miers. Synthesis report. OECD Publishing, Paris. 
OECD (2014). Mental Health and Work: Switzerland. OECD Publishing, Paris.

OECD (2017). Preventing Ageing Unequally, OECD Publishing, Paris.

OECD (2019). Working Better with Age, Ageing and Employment Policies. OECD Publishing, Paris.

OECD (2020). Public Spending Indicators. https://data.oecd.org/socialexp/social-spending.htm [retrieved 2020-08-25].

OECD (2021). Labor force participation rate (indic a tor), Labor Market Statistic s: Labor force statistics by sex and age: indic a tors. https://doi.org/10.1787/8a 801325-en [retrieved 2021-06-25].

OECD.Stat (2020). Educational atta inment and labor-force status: Employment, unemployment and inactivity rate of 25-64 year-olds, by educational atta inment. https://stats.oecd.org/ [retrieved 2020-08-25].

Office of the Chief Actuary (2019). The long-range economic assumptions for the 2019 trustees report. April. https://www.ssa.gov/oact/TR/2019/2019_Long-Range_Economic_Assumptions.pdf [retrieved 2020-08-25].

Orcutt, Guy H. (1957). A new type of socio-economic system. The Review of Economic sand Statistics, 116-123.

Oreopoulos, Philip, and Uros Petronijevic (2013). Making college worth it: A review of research on the retums to higher education, National Bureau of Ec onomic Research (NBER), Working Paper 19053.

Perez-Arce, Francisco, and Mańa J. Prados (2021). The decline in the US labor force participation rate: A literature review. J oumal of Ec onomic Surveys 35(2), 615-652.

Poterba, J a mes M., Steven F. Venti,, and David A. Wise (2013). Health, education, and the postretirement evolution of household assets. J oumal of Human Capital, 7(4), 297-339.

Scharle, Ágota, Balázs Váradi, and Flóra Samu (2015). Policy convergence across welfare regimes: The case of disability policies. WWWforEurope Working Paper No. 76.

Schuring, Merel, Lex Burdorf, Anton Kunst, and J ohan Mackenbach (2007). The effects of ill health on entering and mainta ining paid employment: evidence in European countries. J oumal of Epidemiology and Community Health, 61(7), 597-604

Seeleib-Ka iser, Martin (2016). The end of the conservative Geman welfare state model. Social Policy and Administration, 50(2), 219-40.

Spielauer, Martin, and Olivier Dupriez (2019). A portable dynamic mic rosimulation model for population, education and health applic ations in developing countries. Intemational J oumal of Mic rosimulation, 12(3), 6-27.

Sutherland, Holly, and Francesco Figari (2013). EUROMOD: the European Union tax-benefit mic rosimulation model. Intemational J oumal of Mic rosimulation, 6(1), 4-26.

TPAM (Technical Panel on Assumptions and Methods) (2019). Report to the Social Sec urity Advisory Board, September 2019.

Van Hook, Jennifer, Ala in Bélanger, Patrick Sabourin, and Anne Morse (2020). Immigration selection and the educational composition of the US labor force. Population and Development Review, 46(2), 321-346.

Vespa, J onathan, David. M. Armstrong, and Lauren Medina (2020). Demographic tuming points for the United States: Population projections for 2020 to 2060. US Census Bureau, Wa shington, DC: US Department of Commerce, Ec 0nomic s and Sta tistic s Administration.

Weber, Daniela, and Elke Loichinger (2020). Live longer, retire later? Developments of healthy life expectancies and working life expectancies between age 50-59 and age 60-69 in Europe. European J oumal of Ageing, 1-19.

Zaidi, Asghar, and Katherine Rake (2001). Dynamic mic rosimulation models: A review and some lessons for SAGE. Discussion Paper 2, Simulating Social Policy in an Ageing Society (SAGE), London. 